\title{
Developmental studies of avian brain organization
}

\author{
LUIS PUELLES* \\ University of Murcia and IMIB-Arrixaca, Dept Human Anatomy, Murcia, Spain
}

\begin{abstract}
Avian brain organization or brain Bauplan is identical with that of vertebrates in general. This essay visits avian studies that contained advances or discussions about brain organization, trying to explain critically what they contributed. In order to start from a specific background, the new prevailing paradigm as regards brain organization, the prosomeric model, is presented first. Next a brief historic survey is made of how ideas on this topic evolved from the start of modern neuromorphology at the end of the 19th century. Longitudinal zonal organization with or without transverse segmentation (neuromeres) was the first overall concept applied to the brain. The idea of neuromeric structure later decayed in favour of a columnar model. This emphasized functional correlations rather than causal developmental content, assimilating forebrain functions to hindbrain ones. Though it became prevalent in the post-world-war period of neuroscience, in the last decades of the 20th century advances in molecular biology allowed developmental genes to be mapped, and it became evident that gene expression patterns support the old neuromeric model rather than the columnar one. This was also corroborated by modern experimental approaches (fate-mapping and analysis of patterning).
\end{abstract}

KEY WORDS: brain axis, longitudinal zone, neuromere, prosomeric model, columnar model

\section{Introduction}

This essay covers the historic sequence of ideas on brain morphologic organization, emphasizing contributions from avian neuroembryology. Malpighi (1673) and Von Baer (1828) already illustrated several brain vesicles in chick embryos, and the latter discovered the notochord (subsequent definition of the length axis). The issue of brain organization (models of brain morphological structure) strongly implies comparative evolutionary analysis. Avian studies did not occur in isolation, but in the context of parallel studies in other vertebrates, mainly in mammals. The two historic brain organization models I'll discuss below -the neuromeric and columnar models- postulate general validity in all vertebrates. The following account is not impersonal, since I did not pretend to ignore my own contributions and opinions, but does attempt to set the whole in perspective. Some anecdotic personal information may help understanding what happened. I acknowledge that the same story told by others might be slightly different.

\section{Present concept of brain organization}

The modern concept of brain organization (or brain Bauplan) distinguishes a submarine-like neural primordium; this implies a length axis, symmetric right and left halves, rostral and caudal terminal regions (prow and stern), as well as floor and roof domains (Fig.1). The conventional idea of a 'closed neural tube' is a misleading metaphor, since it wrongly suggests that there exists a tube with open terminal brain regions, which would correspond to the rostral and caudal neuropores. However, fate-mapping shows that the transient neuropores are not the developmental antecedents of the terminal brain regions, but just the last parts of the roof plate that close during neurulation (Fig.1C; Puelles et al., 1987a; Cobos et al., 2001). The flat neural plate primordium (prospective brain; Fig.1A) already contains the future terminal regions and then acquires a canoe shape by elevation of its periphery above the floor plate. Distinct terminal regions and lateral walls are thus formed, but there is no roof yet; a notochord-related ventral floor differentiates (Fig.1B). Neurulation then sets in, by gradual closure of the prospective median roof domain. The earlier free borders fuse first at intermediate levels, and this process extends in both directions; diminishing rostral and caudal neuropores (non-fused regions) are visible transiently (Fig.1C). Neurulation transforms the early open canoe into a submarine-like closed shape (Fig.1D). The prospective median part of the rostral terminal region (the

Abbreviations used in this paper: AChE, acetylcholine; AP, antero-posterior; DV, dorso-ventral.

\footnotetext{
*Address correspondence to: Luis Puelles. University of Murcia and IMIB-Arrixaca; Dept Human Anatomy, Murcia 30120, Spain. E-mail: puelles@um.es (iD) http://orcid.org/0000-0002-9541-7073
} 
A

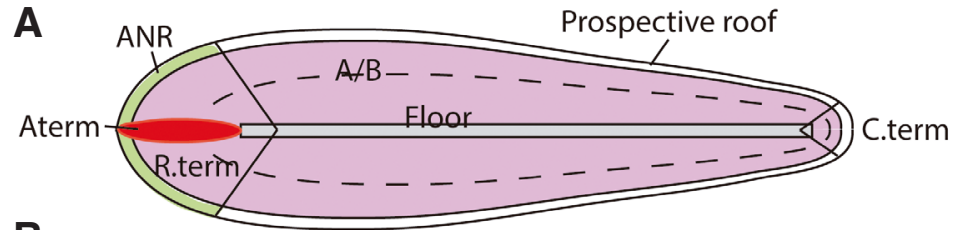

B
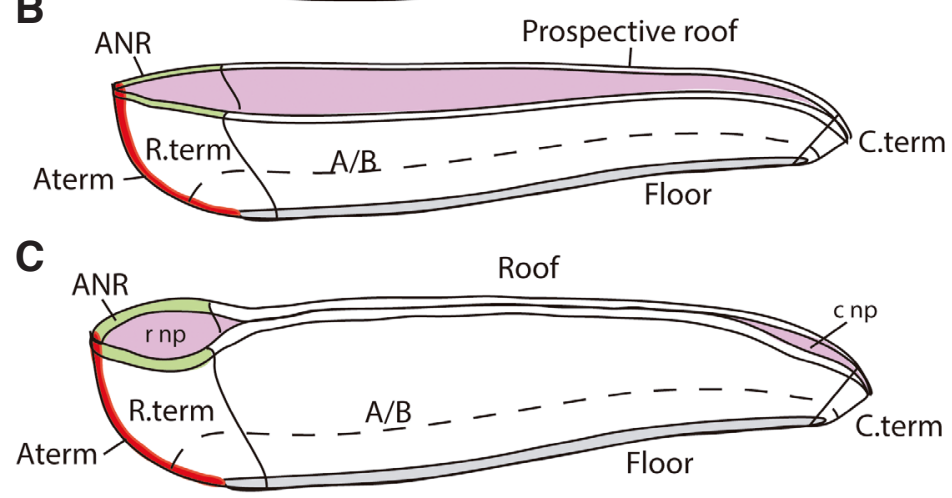

D

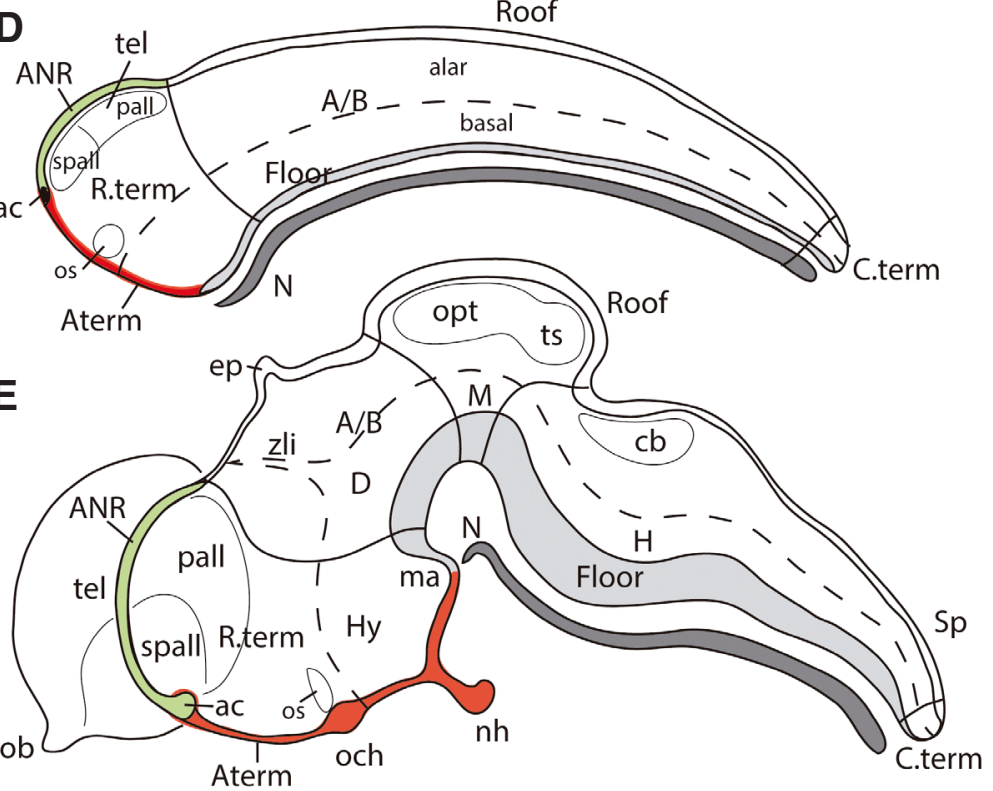

Fig. 1. The five steps of the neurulation process, keeping track of various characteristic prospective structures. (A) The open neural plate, featuring a median floor plate primordium (gray bar) that does not reach either the rostral or caudal ends of the plate (rostral to the left). The prospective roof plate is represented by the entire ridge that borders the neural plate (neural/non-neural border); a distinct anterior sector of this ridge (labelled here in green) represents the anterior neural ridge (ANR), known to have important patterning roles; it produces no neural crest cells, and is related by fate and induction to the prospective telencephalon (fate maps place the subpallium most rostrally within the ANR, and the pallium caudally; compare spall and pall in $(D, E))$. The caudal limit of the ANR thus announces the future border between the secondary prosencephalon and the diencephalon (see E). The prospective secondary prosencephalon is marked here as rostral terminal region (Rterm; limited by straight lines). The midline of Rterm contains the acroterminal domain (Aterm; in red), which extends between the rostral tip of the floor plate and the midpoint or rostralmost end of the ANR. The schema also shows a caudal terminal region at the caudal end of the neural plate (Cterm). The pink area that fills the neural plate represents the prospective ventricular surface of the neural tube (it will thus gradually become hidden as neurulation proceeds; see $(B, C)$ ). Finally, the prospective alar-basal boundary is represented by a dash line $(A / B)$; note this line bends rostrally to the end of the floor plate and crosses orthogonally the Aterm, thus defining alar and basal domains within the Rterm and the Aterm. A similar crossing is observed at the Cterm (this is consistent with work of the Le Douarin lab cited in the text). (B) The 'canoe' shape stage at the beginning of neurulation, seen from the side (rostral to the left). Using as a hinge the floor plate, the bilateral halves of the neural plate rise up, momentarily forming this canoe-shaped fully open configuration, because the Rterm and Cterm regions likewise rise up. There is now much less future ventricular surface (pink) visible. Note the invariant floor plate and similar prospective roof and ANR domains, as well as the Aterm domain now elevated, forming the median prow of the canoe. the alar-basal boundary $(A / B)$ has not changed and still crosses rostrally the Aterm, dividing the Rterm and Aterm into alar and basal moieties. (C) At this stage of advanced neurulation we see the rostral and caudal neuropores ( $\mathrm{n} n \mathrm{p} ; \mathrm{c} n \mathrm{p}$ ) as the single sites where we can still see the neural ventricular surface (pink). This change is due to the extensive midline fusion of the roof plate ridges (Roof). Note the halves of the ANR (green) have not fused yet. Once fusion ends, the canoe will have transformed into a closed 'submarine-like' shape. Note the neuropores do not represent really the anterior and caudal ends of a 'neural tube', as this metaphor suggests; they are just late fusing parts of the roof plate. This means the ANR transforms after fusion into the roof of the secondary prosencephalon, that is, the septal commissural plate. (D) Once neurulation ends, the neural 'tube' is a closed fluid-filled shape that separated from the neural crest and other cutaneous neighbours. At this stage the axial notochordal rod ( $N$; dark gray) strictly parallels the extent of the floor plate (light gray), both clearly ending now under the secondary prosencephalon (Rterm). The dorsalmost area of Rterm contains the telencephalic primordium, with the rest of the ANR at its midline roof domain (green), which ends at the primordium of the anterior commissure (ac; black spot), also representing the dorsalmost part of the Aterm (which ends ventrally at the midline of the primordium of the mamillary body (ma in (E))). Note this confluence of ANR and Aterm at a particular point is already observed in the open neural plate (A). Next to the alar part of the Aterm we see the optic stalk (os). The prospective subpallium and pallium (spall, pall) are placed rostrally and caudally under the ANR (green), as revealed in fate mapping experiments. The rest of the Rterm domain represents the alar and basal parts of the hypothalamus (Hy in (E)). (E) As development proceeds, differential growth sets in, causing an important ventralwards axial bending (the cephalic flexure, seen above the notochordal tip). The different characteristic morphologic zones we have been following nevertheless retain their mutual relationships, as seen by the colored coding (ANR, green; Aterm, red; floor plate, light gray; notochord, dark gray; alar-basal boundary, dash line). We recognize now the proneuromeric compartments of the forebrain tagma (secondary prosencephalon, or Rterm; diencephalon, $D$; midbrain, M). the telencephalic vesicle is now evaginated and has grown the olfactory bulb diverticulum (ob). We see by transparency its division into subpallial and pallial territories; due to the cephalic flexure, the topologically rostral subpallium (spall) appears now 'ventrally' to the pallium (pall), but their mutual primitive relationship seen in (D) has not changed (subpallium close to the anterior commissure (ac), pallium in part close to the diencephaIon; differential growth in favour of the pallium causes it to progressively surround the subpallium. Finally, note the Aterm domain now has developed some specialized derivatives, which include the preoptic lamina terminalis, the optic chiasma (och), the median eminence and infundibulum, with the neurohypophysis (nh), and the tuberomamillary area (unlabelled). Other dorsal outgrowth start to emerge, namely the optic lobe in the midbrain, with rostral optic tectum (opt) and caudal torus semicircularis (ts); note space is left for the rostral tectal gray domain and the caudal preisthmus, which lack outpouchings. In the hindbrain (H) the locus of the incipient cerebellar expansion is marked (cb). 
prow), recently characterized as the acroterminal area (Puelles et al., 2012a; Puelles and Rubenstein, 2015; Ferran et al., 2015), can be mapped at early neural plate stages within the larger rostral terminal region, which encompasses the full secondary prosencephalon (prospective hypothalamo-telencephalic region; Fig. 1A). The lateral neural walls as well as the terminal regions result secondarily patterned dorsoventrally (DV pattern) into alar and basal longitudinal zones, by agency of antagonistic dorsalizing and ventralizing signalling from the roof and floor zones. The rostral ends of all the longitudinal zones are acroterminal, and the alar and basal plates are primarily continuous from left to right (Fig. 1A; Shimamura et al., 1995; Puelles, 1995; Kiecker and Lumsden, 2012). In parallel, there successively emerge transverse tagmatic, proneuromeric and neuromeric subdivisions (anteroposterior pattern $[A P]$ ), by agency of acroterminal (rostralizing) and caudal (caudalizing) terminal signals.

Note the process of rostral terminal AP signalling is confusingly biased in the experimental developmental literature towards ascribing an exclusive role as signal source to the terminal roof plate (i.e., the anterior neural ridge [ANR], which has a median acroterminal portion and paramedian wings; Fig. 1 A-D). This implicit postulate disregards the potential role of additional signals spreading from the complementary rostralmost alar, basal and floor acroterminal domains. In fact, the model suggests that true AP signals likely should optimally originate and diffuse caudalwards from acroterminal alar and basal organizers (Puelles, 2017), whereas the acroterminal median roof and floor domains probably generate DV signals that act upon the acroterminal region itself (Fig. 1C). Terminal, but nonacroterminal, roof signals coming from the caudal wings of the ANR probably participate mainly in DV patterning of telencephalon, eye field and alar hypothalamus (Fig. 1 D,E).

Primary longitudinal zones due to dorsoventral patterning are the floor, basal, alar and roof plates (His, 1893), though there are secondary smaller-microzonal-subdivisions of these domains, due to finer results of dorsoventral patterning that specify multiple alar and basal microzones uniquely in terms of their molecular profile (i.e., sets of active and inactive genes; review in Puelles, 2013). The rostral terminal and acroterminal areas share primarily -i.e., already at neural plate stages- the dorsoventral partitions of the lateral walls of the neural tube (Fig. 1E).

Orthogonal intersection of DV and AP patterning effects defines in the neural wall a number of large and smaller rectangular progenitor areas, each exhibiting increasingly stable and unique regional molecular specification codes. All of them show secondary regionalization (further partitioning) through the agency of so-called 'secondary organizers', so that smaller regions and subregions eventually obtain added differential molecular specification. This results in specific neurogenetic and histogenetic patterns obtaining within microzonal neuroepithelial areas known as progenitor domains or histogenetic areas, characterized by unique tridimensional growth properties (radial dimension is added here), with details that often change in different vertebrate species. There results species-specific morphological shaping (topological deformation) of the fundamental brain organization plan (Bauplan). Large evaginated vesicles such as the eyes, the telencephalic vesicles, the midbrain tectum and the cerebellum emerge, whose differential growth accounts for the largest species-specific differences. However, they are just local expansions of particular alar neural microzonal or pluri-microzonal subdivisions (Fig. 1E). In some cases these outgrowths become large enough that they result themselves patterned further into distinct neuroepithelial regions (e.g., eye primordium into optic stalk, pigmented retina, iris, ciliary body, and neural retina; telencephalon into pallium and subpallium and orthogonal septoamygdaloid variations; midbrain tectum into tectal gray, optic tectum, torus semicircularis and preisthmus; cerebellar primordium into vermis, hemisphere and floccule). Additional median outgrowths of the primary neural primordium are represented by the neurohypophysis and the epiphysis (Fig. 1E).

Other brain subdivisions are those that appear orthogonally disposed relative to the neural length axis, namely the forebrain, hindbrain and spinal initial tagmata (Fig. 2A) and their ulterior proneuromeric divisions and neuromeric subdivisions (Fig. 2 B,C). The forebrain tagma is divided into secondary prosencephalon (hypothalamo-telencephalic complex), diencephalon, and midbrain proneuromeres (Fig. 2B); the hindbrain tagma is divided into prepontine, pontine, retropontine and medullary proneuromeric regions (Fig. $2 \mathrm{~B}$ ), and the spinal tagma is divided into pretrematic, rostral trematic, intertrematic, caudal trematic and posttrematic regions (not shown; 'trema', Greek = limb). Each proneuromeric domain generates a few neuromeres. These represent smaller transverse developmental units with differential neural fates (Fig. 2C). These transverse limits (AP pattern), similarly as the DV limits that separate longitudinal zones and microzones, are related to differential molecular profiles (Fig.3; see also Fig.8; details in Puelles, 2013). Some of the transverse interneuromeric limits coincide with particular properties, such as restriction of proliferative clonal dispersal of neuroepithelial progenitors, low proliferation rates, particular adhesivity markers, and reduced junctional permeability, which jointly cause the characteristic interneuromeric constrictions seen between overt neuromeres, particularly overt rhombomeres (blue background in Fig. 2C; Heyman et al., 1993, 1995; Martínez et al., 1992, 1995). There exist other such transverse boundaries that separate cryptic neuromeres in the hindbrain, midbrain and forebrain, which seem so far delimited mainly by molecular and fate boundaries (Puelles and Rubenstein, 1993, 2003, 2015; Cambronero and Puelles, 2000; Marin et al., 2008; Tomás-Roca et al., 2016; Ferran et al., 2015). As regards histogenetic behavior (generation of neuronal types, nuclear boundaries, axonal guidance fields, or topographically-organized synaptic fields) no difference is observed between overt and cryptic neuromeres.

Notwithstanding very remarkable species-specific quantitative differences in neural development, comparative neuromorphologists regard the deduced brain Bauplan as reflecting a topologic (invariant) bidimensional map that is eminently conserved across all vertebrates, implying a shared set of patterning mechanisms and brain progenitor regions. The common two-dimensional Bauplan is variously translated evolutionarily into the third, radial dimension. This generates field homologies (i.e., one-many correspondences of microzonal units across different species). Field homology is accordingly what we deal with when brain parts are compared in different vertebrate species. In contrast, progenitor domains taken as undifferentiated primordia can be strict homologs, judged by their relative position, molecular profile, and neighbours, irrespective of differential areal size (Puelles and Medina, 2002; Nieuwenhuys and Puelles, 2016). The cause of brain Bauplan stability in spite of radiating evolution is probably represented by intrinsic constraints imposed by the high complexity of the nervous system (Kauffman, 1993, 2008), as well as by networked genomic 
Fig. 2. Three steps in the progressive anteroposterior (AP) subdivision of the neural tube postulated in the prosomeric model (the spinal cord, Sp, is disproportionately reduced in size). In all cases the rostral roof plate portion identified as the anterior neural ridge (ANR; prospective septal commissural plate) is colored in green (the roof ends at the anterior commissure (compare ac in Fig. 1E); the acroterminal rostral midline of the forebrain is colored in red (note its roof, alar, basal and floor subdomains); the floor plate is colored in light gray, and the notochord in dark gray. (A) The set of three tagmatic regions, limited by thick black lines, each of which is characterized by subdivisions that share some regional characteristics (the concept of 'tagma' comes from insect anatomy, whose body is divided into head, thorax and abdomen tagmata, each of which is divided into a number of segments that share a family resemblance irrespective of their individual differences). The forebrain (FB) is the rostralmost tagma in the brain of vertebrates (sometimes called 'archencephalon'). Gene expression evidence and histogenesis show various shared patterns throughout this domain (e.g., Otx2 expression, Shh expression in the floor and basal plates; Nkx2.2 expression along the alar-basal boundary; the floor plate domain produces dopaminergic neurons). Next comes the hindbrain (HB) tagma (Shh expressed only at the floor plate, and Nkx2.2 expressed at the boundary between floor and basal plates; site where serotonergic neurons are selectively produced; alar plate labelled uniformly with Pax7). Finally, the spinal cord (Sp) also represents a tagma, since all its portions and hypothetic segments (myelomeres) share likewise a similar cellular structure, irrespective of individual specializations. A line with small dashes delimits the telencephalon from the hypothalamus; this places the unevaginated preoptic area (poa) inside the telencephalon. (B) The larger proneuromeric AP regions, divided by slightly thinner topologically transverse lines (always orthogonal to alar-basal boundary), which have received historically distinct anatomic names, but are not yet neuromeres. Note all of them are alar+basal complexes (alar-basal boundary as a dash line; the zli spike is not really a part of this boundary, being a transverse alar plate feature, but many gene markers -e.g., Nkx2.2- show this type of continuity between them [see Fig.7C insert and Puelles and Martínez, 2013; Martínez-Ferre etal., 2013 for explanation]). The forebrain tagma divides into three proneuromeres: 1) the secondary prosencephalon (Sec.Pros., sum of telencephalon, eyes and hypothalamus); 2) the diencephalon proper (Di); and 3) the midbrain (Mes). In its turn, the hindbrain tagma shows four proneuromeric divisions: 1) the isthmocerebellar or prepontine domain (PrP); 2) the pontine domain ( ; contains selectively the postmigratory basilar pontine nuclei); the retropontine domain (RP, contains the trapezoid body); and 4) the medullary region (Med). The divisions of the spinal cord are mentioned in the text. (C) The final neuromeric units (thinner transverse limits). Note there are two hypothalamo-telencephalic prosomeres (hp1, hp2), three diencephalic prosomeres (dp1, dp2, dp3), two midbrain prosomeres (also called mesomeres; $\mathrm{mp} 1, \mathrm{mp} 2$ ), and 13 hindbrain rhombomeres, divided into groups according to the proneuromere they derive from: $r 0$ (isthmus) and rostral and caudal parts of $r 1$ are prepontine cryptorhombomeres (rO, $r 1 r, r 1 c)$; $r 2-r 4$ are pontine overt rhombomeres (note $r 2$ only contains pontine fibers coursing towards the cerebellum around the trigeminal nerve root, while the pontine nuclei proper lie in r3-r4); r5-r6 are retropontine overt rhombomeres (they do not participate in the pons proper, though in species with large pontine bulges, like the human, these may partly overhang the retropontine region, hiding it); finally, r7-r11 are medullary cryptorhombomeres, ending just rostral to the pyramidal decussation. The only overt (well-delimited) rhombomeres are the pontine and retropontine ones ( 2 -r6; colored with blue background). This emphasizes that only a small fraction of the entire set of brain neuromeres obeys Lumsden's criteria of metamery based on clonal restriction. This author tends to wishfully misidentify the r2-r6 set of units as 'the rhombencephalon'. Note also that the cerebellum (compare Cb in Fig. 1E) has distinct vermal, hemispheric and floccular portions agreeing with the three prepontine units it extends through (ro, r1r, r1c).
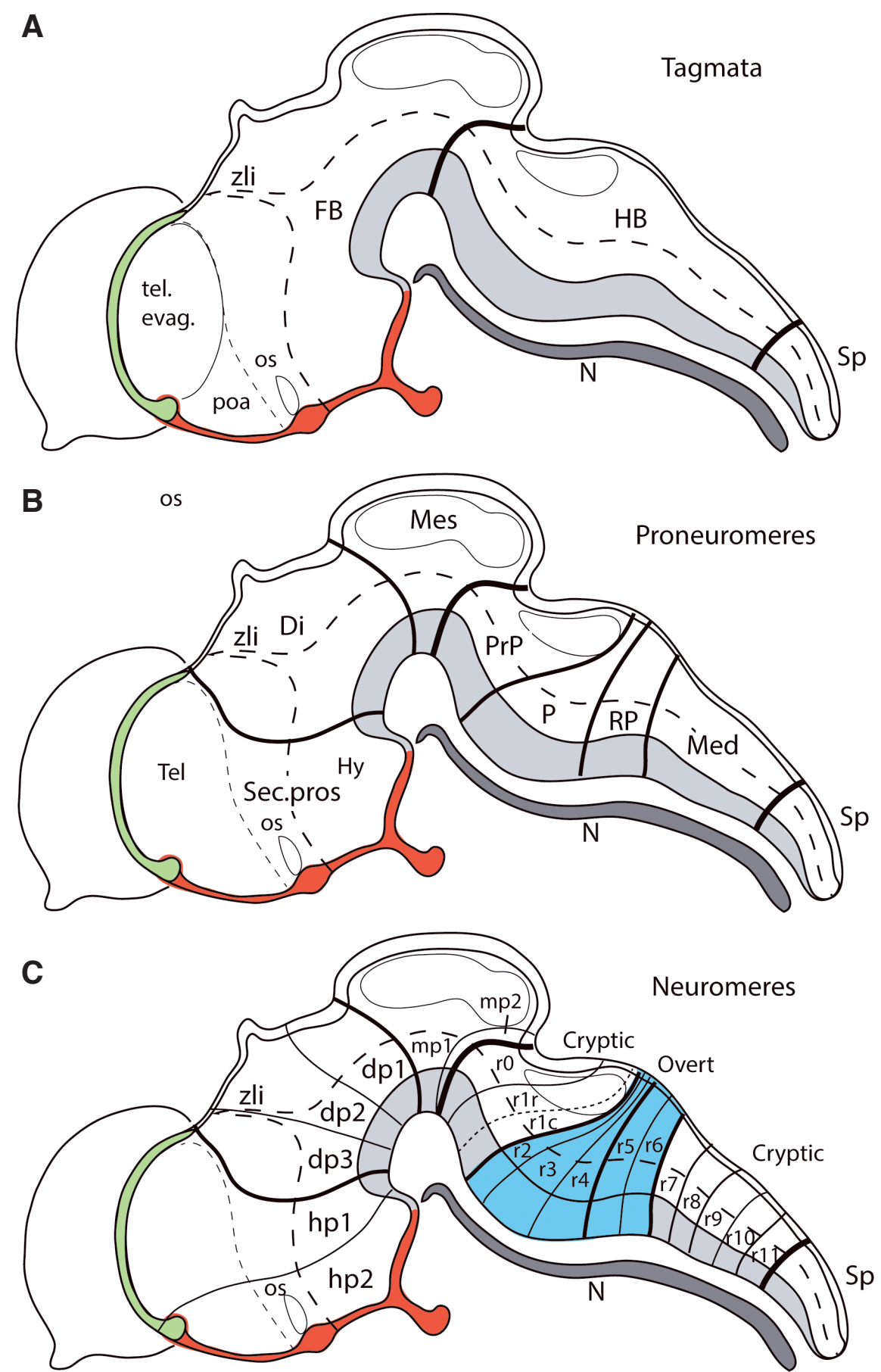
and epistatic regulatory capacities, so that essentially the same fundamental developmental course is followed irrespective that underlying molecular DNAcodes and tri-dimensional protein shapes permanently vary in aleatory ways.

\section{Overall view of historic changes in concepts about brain organization}

Morphologic analysis of the developing brain first followed historically the hypothesis of a general longitudinal organization (His, 1970, 1892, 1893a,b, 1894, 1895, 1904; Orr, 1887), with a notochord-related axial concept and accompanying notions such as floor plate, alar-basal limit and roof plate, that is, the tetrapartite longitudinal zonal model of His (Fig.1 E,2; 4). This concept was complemented by the idea of a concurrent neuromericorganization, orthogonal to the same length axis (Orr, 1887). Various neuromeric models not always agreeing in the number and definition of the transverse units were proposed (e.g., McClure, 1890; Locy, 1895; Neal, 1898; Hill, 1898, 1899; von Kupffer, 1906; Johnston, 1909; Neal, 1919).

These early models were largely superseded by the arrival of the columnar brain model of Herrick-Kuhlenbeck (Herrick, 1910, 1933, 1948; Kuhlenbeck, 1927, 1935, 1936, 1954, 1973), irrespective of the continued existence of some authors interested in neuromeres and longitudinal zones up to the advent of gene mapping (e.g., Tello, 1923, 1934; Wedin, 1955; Coggeshall, 1964; Vaage, 1969, 1973; Gribnau and Geijsberts, 1984; Puelles and Martínez-de-la-Torre, 1987; see references in Puelles et al., 1887b). The columnar model disregarded transverse neural segments altogether, and placed instead strong emphasis on 'columnar organization' (Fig. 3). This concept emerged from the work of Gaskell (1886, 1889), Johnston (1902) and Herrick (1903) on hindbrain longitudinal columns in the adult mantle zone that either originate or receive functionally distinct nerve components of the cranial nerves (visceral and somatic efferents and afferents). Herrick (1910) extrapolated this functional columnar concept to the forebrain (mainly the diencephalon; Fig. 3). What usually is not noticed is that Herrick (1910) and ulterior columnar authors uniformly employed an arbitrarily changed forebrain axis that is unrelated to the notochord, disregards the cephalic axial flexure, and ends inside the telencephalon (Fig.3 A,B; compare Figs. 2,4). This model was strongly driven by American authors working on the forebrain, and became generally prevalent in the post-worldwar period. Some postwar neuromeric scientists also started to use a columnar forebrain axis ending in the telencephalon (e.g., Bergquist, 1952; Bergquist and Källén, 1953a,b, 1954 ; Keyser, 1972), though this was explicitly corrected in Bergquist and Källén (1955). In any case, neuromeres were finally practically forgotten, and fell out of textbooks.

Curiously, the columnar model, which was the prevalent paradigm during the important era of modern cytoarchitectonic, myeloarchitectonic and experimental neuroanatomy (with added subsequent histochemical or immunocytochemical brain analysis and hodological work based on axonal transport), is now regarded as being obsolete, at least by embryologists. Swanson $(2003,2012)$ is a relevant, present-day example of a columnar neuroanatomist who delves scholarly with selective embryonic data (no neuromeres; no axial argument). Columnar thinking seems no longer to offer an useful brain model due to the circumstance that its tenets on fore- brain organization lack experimental causal support (for instance, in the case of holoprosencephaly syndromes, they should not leave the rest of the diencephalon untouched when the hypothalamus is deleted; Fig. 3). Actually, the columnar model never pretended to offer causal explanations, since from its origin (Herrick, 1910) it concentrated on hypothetic functional insight on the adult brain. As we will see below, Kuhlenbeck (1927, 1936, 1973) applied the idea of adult columns limited by sulci to embryonic stages, but also abstained from causal theorizing. There never existed a developmental hypothesis suggesting how a column later transforms into multiple nuclei. The entire hypothalamus with dozens of nuclei appears as a homogeneous column (Fig. 3); Swanson $(2003,2012)$ later mapped many nuclei therein, but still offered no

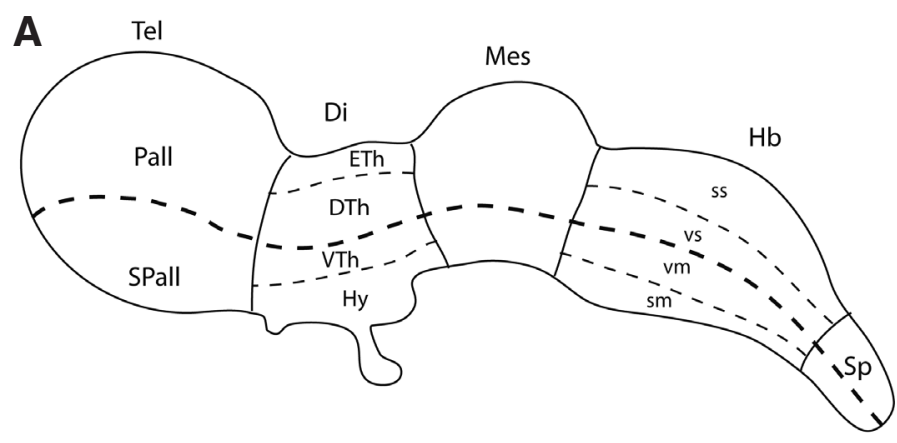

B

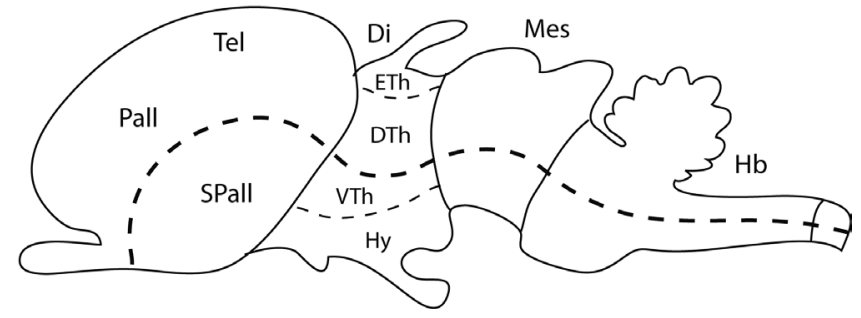

Fig. 3. Synthetic drawing of the columnar model as postulated by Herrick (1910). It emphasizes his implicit and non-discussed forebrain axis (seen here as a heavier dashed line) ending in the telencephalon; note the unnoticed difficulty that there are two hemispheres, so that implicitly such an axis must bifurcate somewhere to reach both vesicles. The four diencephalic columns were explicitly compared functionally and in 'longitudinal position' with those in the hindbrain. The thick and the thinner dash lines represent ventricular sulci. Initially, Herrick (1910) also extended his four columns into the telencephalon, but this was criticized by contemporaries (e.g., Johnston, Kuhlenbeck), given that only the hypothalamus is demonstrably continuous with the telencephalon; so this aspect was no longer part of the model subsequently, but nobody said officially how the DTh and ETh end rostrally; I am not aware that Herrick ever applied the idea of four columns to the midbrain, possibly because he found no correlative sulci there. Note also that this model ignores the pretectum, which often was arbitrarily split into diencephalic and midbrain parts; a similar problem appears at the preoptic area. (A) An embryonic stage. Note the tendency to straighten out the cephalic flexure under the midbrain (compare Fig. 1E). (B) Columnar model in an adult rodent. An adult stage, representing the well-established dogma we all see in the literature. Abbreviations: Tel, telencephalon; Di, diencephalon; DTh, dorsal thalamus (thalamus); ETh, epithalamus; Hb, hindbrain; Hy, hypothalamus; Mes, mesencephalon; Pall, pallium; Sp, spinal cord; Spall, subpallium; sm, somatomotor column; ss, somatosensory column; vm, visceromotor column; vs, viscerosensory column; VTh, ventral thalamus (prethalamus). 
causal mechanisms. More pragmatically, the columnar model also proved unable to explain numerous gene expression patterns that have accrued since the mid-eighties. Firstly, these results support the axial concept of traditional neuromeric models (as originally defined by Orr, 1887 and His, 1892, 1893, 1895), and firmly place the telencephalic vesicles as dorsal microzonal derivatives of the hypothalamic alar plate (i.e., they negate their terminal topologic nature, postulated by columnar authors; compare Figs.1 D,E; 3). Secondly, many gene patterns clearly demonstrated transverse neuromeres and neuromere-derived domains or other features (glial, axonal, synaptic), consistently with parallel fate-mapping and transgenic-labelled progeny data that have extrapolated visible or cryptic embryonic neuromeric units into permanent derived counterparts in the adult brain. This paradigm change has been occurring since the nineteen eighties, as we have been learning more about causal explanation of brain structure. Textbooks and atlases are starting to register the paradigm change as well (e.g., Puelles et al., 2007, 2008; Nieuwenhuys et al., 2008; Watson et al., 2010; Nieuwenhuys and Puelles, 2016).

A
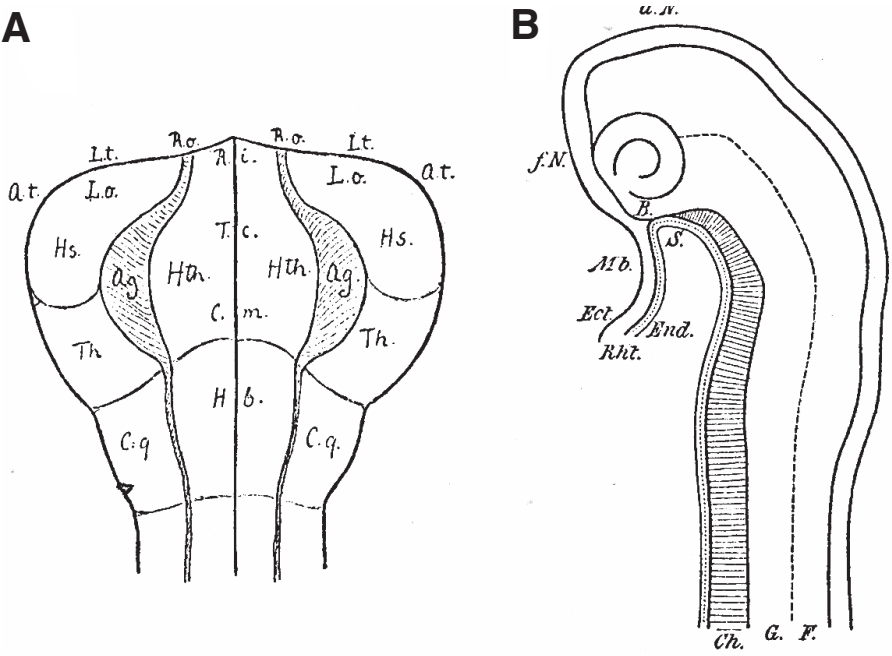

The main current brain organization paradigm accordingly recovers neuromeric brain models that explicitly incorporate brain segmentation as the fundamental AP partitioning principle, while longitudinal zonal division defined again in context with the old notochord- and floor/roof-related axial concept is the main DV regionalizing principle (Figs.1,2,4,8). The variants of such a model depend on how many neuromeres are postulated or which are the metamery criteria employed (see the case of Lumsden in the last section). Shimogori et al., 2010 implicitly tried to conciliate the incompatible columnar and neuromeric axes of the hypothalamus, conceiving an aberrant 'diagonal direction'. I believe the increasingly prevalent concept is represented by the progressively updated versions of the 'prosomeric model' (Figs.1,2,4,8; Rubenstein et al., 1994; Puelles and Rubenstein, 1993, 2003, 2015). Uncommonly in the field, its assumptions, factual evidence, past errors, and interpretive rationale have been transparently exposed.

\section{Seminal work by Wilhelm His}

Systematic morphologic (formanalytic) and developmental analysis of vertebrate brains, including the chicken brain, was

Fig. 4. Drawings extracted from the work of W.His, illustrating his notions about brain organization. (A) Conjectured fate map of the shark brain at the neural plate stage, from His (1893a). The floor plate (median line; includes Tc, Ri), basal plate (marked with $\mathrm{Hb}, \mathrm{Cm}$ and $\mathrm{Hth}$ ), and alar plate (Cq, Th, Hs, Lo) jointly reach the anterior end of the neural plate. See meaning of abbreviations below. The alar-basal boundary (dotted area) expands in the forebrain to include the eye anlage (before it evaginates). The Ri, Ro Lt and At are bilateral landmarks along the front of the neural plate, which he thought fused together during neurulation las a part of the anterior neuropore; the optic chiasma would lie between Ri and Ro), producing his 'frontal suture' (subsequently shown to be non-existent; see text; the eye area is also in disagreement with modern results). Compare the same landmarks with their position in the closed tube in (C). Abbreviations: Ag, eye primordium; At, angulus terminalis (prospective neuroporic recess); $\mathrm{Cm}$, mamillary body; $\mathrm{Cq}$, corpus cuadrigeminus (midbrain); $\mathrm{Hb}$, tegmentum (basal plate); Hs, telencephalic pallium; Hth, hypothalamus; Lo, olfactory lobe (subpallium); Lt, lamina terminalis; Ri, infundibular recess; Ro, optic recess; Tc, tuber cinereum (infundibulum); Th, thalamus. (B) Lateral view of a shark embryo, from His (1892), showing his idea of the early notochord (Ch) underlying strictly the neural floor plate (note also the position of the anterior endoderm pouch, S, Seessel's pouch), and the parallel course of the alar-basal boundary ( $G$, basal plate; F, alar plate). $d N$ and $\mathrm{fN}$ are respectively the frontal and dorsal sutures he thought closed the rostral neuropore. (C) Midline section of the closed tube from a human embryo, showing the floor plate ending at the infundibular recess (Ri and meeting there the fused roof plate), the alar-basal boundary ending at the optic recess (Ro; the optic chiasma lies between $R i$ and $R o$ ) and the dorsal roof plate ending at the terminal angle (neuroporic recess, possibly ulterior site of the anterior commissure (note Lt: lamina terminalis, which extends between this commissure and the optic chiasma (frontal fused roof plate). In this schema thalamus and telencephalon are entirely alar structures (this would include the non-identified prethalamus, pretectum and alar midbrain). In contrast, the hypothalamus is identified as a rostral basal plate territory, continuous caudally with the brainstem tegmentum (note isthmus -Is- identified as a ventral neuromere-like bulge). I added in red the main transversal boundaries he introduced in His (1895); these illustrate what he meant with 'diencephalon sensu stricto' (an alar+basal complex ending ventrally at the mamillary region, $\mathrm{Rm}$ ) and 'telencephalon sensu lato' (an alar+basal complex containing telencephalon and infundibular hypothalamus). Compare with prosomeric transverse boundaries in Fig. 2 A-C. 

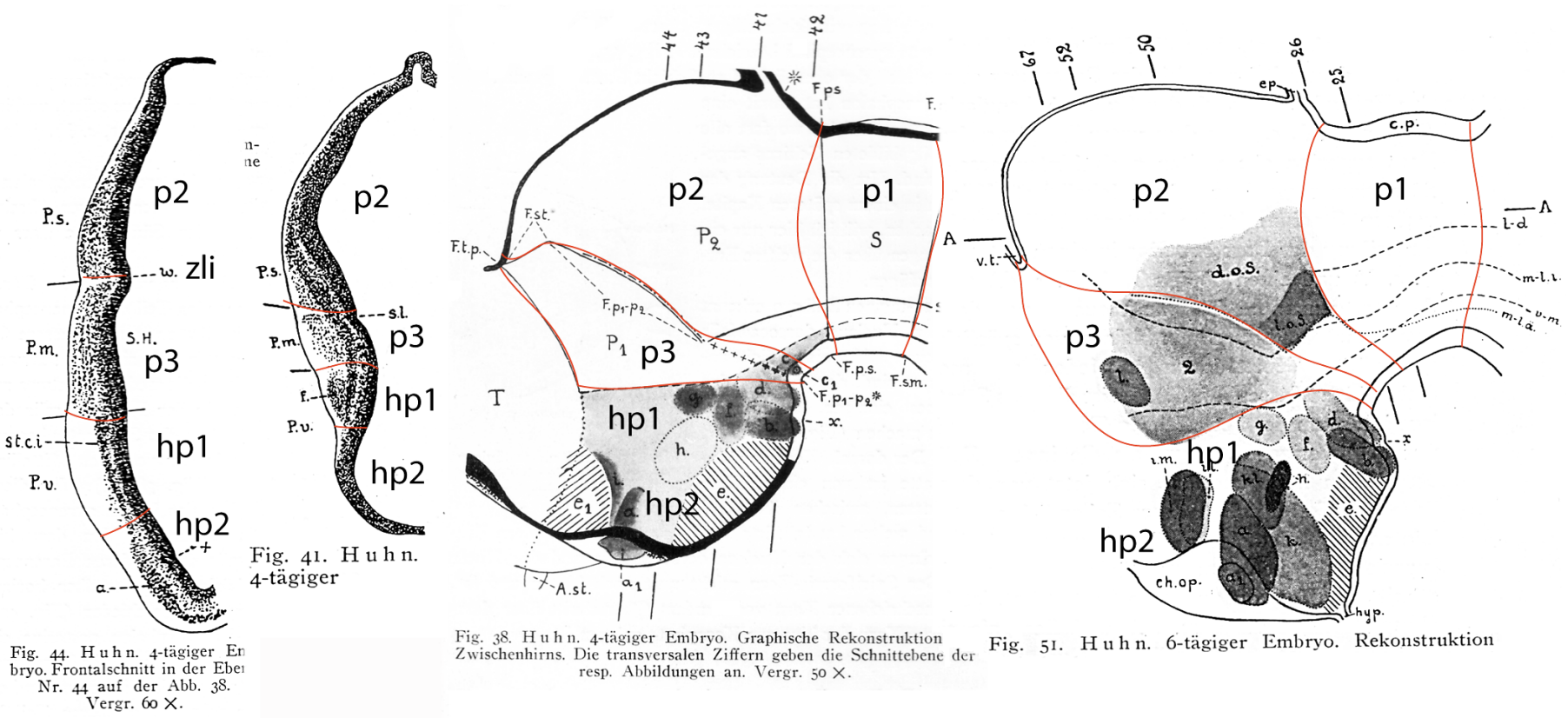

Fig. 5. Panel collecting images from Rendahl's 1924 publication on the developing chick diencephalon, including two representative sections from a 4-day-old chick embryo at left (original captions mark them as Rendahl's Figs.44 and 41, respectively), a graphic reconstruction of this same 4-day-old diencephalon (Rendahl's Fig.38), with marked section levels for four sections (this includes the ones shown at left), and another graphic reconstruction of a 6-day-old chick diencephalon (Rendahl's Fig.51). There is no need to enter into the complex terminology and abbreviations of this author. I have added tags indicating the modern prosomeric interpretation of diencephalic and hypothalamic prosomeres (p1-p3; hp1, hp2; compare Fig. $2 C)$, and retraced in red on the reconstructions the relevant interprosomeric boundaries. The two sections at left intersect what we now call thalamus (p2) and prethalamus(p3) and their mutual characteristic zli boundary, before continuing into the hypothalamus, where histogenetically distinct sectors best visible in Fig. 44 correspond to what we now interprete as hp1 (typically traversed by the telencephalic peduncle) and hp2, sectioned at the level of the precociously developed anterobasal area, just under the optic chiasma (classic retrochiasmatic area). Section in Fig. 41 intersects more ventral parts of $\mathrm{p} 2$ and $\mathrm{p} 3$ and also shows histogenetic difference between the hypothalamic hp1 and hp2 domains (see also corresponding reconstruction). The graphic in Fig.38 shows some longitudinal zones in the diencephalon, running orthogonal to the interneuromeric boundaries (the latter retraced in red); this clearly shows that the hypothalamus must lie rostral to the diencephalon, rather than ventral to it, as held in the columnar model (see Fig.3). The sections at left are therefore horizontal to the neuromeric units rather than cross-sections. The reconstruction of the 6-day stage at the right reproduces the same pattern, but in the presence of more advanced mantle differentiation. It can be seen that each neuromere produces its own cell populations. Remarkably, the p2 (thalamic) mantle is starting to become compressed anteroposteriorly between p1 and p3, particularly ventrally. The thalamic early superficial population labelled as d.o.S and I.o.S. (referring to 'dorsal and lateral parts of the superficial layer' - [oberflächliche Schicht], which jointly build one single nuclear primordium, the superficial magnocellular nucleus, SM). This is the cell group we selected to test the postulate of Kuhlenbeck $(1935,1936,1937)$ that diencephalic columns form across the former interneuromeric boundaries as homogeneous cell masses, within which definitive nuclei only form later (see our Fig.6).

started by His $(1870,1892,1893 a, b, 1894,1895,1904)$. He first noticed the correlative topography of the notochord and the floor plate of the neural tube (Fig. 4B), pointing to the primary neural axis irrespective of ulterior morphogenesis (Fig. 4C). He illustrated chicken neurulation (roof plate). He also first defined the alar and basal plates (in shark and human embryos; Fig. 4B; basal areas are precocious in neurogenesis and mantle development). His also pioneered a flat fate map of the neural plate, where he speculatively projected prospective subdivisions (Fig. 4A; His, 1893b). He was wrong in holding that the rostral neural plate border corresponds to the prospective optic chiasma (Fig. 4 A,C; see Fig. 1E), and in his idea of a frontal (terminal) closure of the rostral neuropore; experimental chicken evidence corrected these points (Puelles et al., 1987a; Cobos et al., 2001). Though the contemporaneous lizard embryo work of Orr (1887) defined histologically and first named transverse hindbrain and forebrain bulges as 'neuromeres', His never mentioned neuromeres, like other major neuromorphologists such as Edinger and Ramón y Cajal, though the latter's pupil Tello
(1923, 1934) did illustrate neuromeres in his neurofibrillary studies of chick and mouse embryos, probably with his master's nihil obstat (Puelles, 2009). The only implicitly segment-like neural tube unit identified by His (1893b, 1895, 1904) was the isthmus (Fig. 4C), postulated as a neuromere in some modern neuromeric models (chick studies of Vaage, 1969, 1973; Puelles and Martínez-dela-Torre, 1987b), a notion that was recently supported in mice by transgenic progeny analysis (Watson et al., 2017).

\section{The first wave of neuromeric studies}

Analysis in context with head segmentation theories and badly fixed embryos (postmortem damage) characterized the earliest studies on avian neuromery. This caused the myth that neuromeres were artefacts. However, well-delimited hindbrain neuromeres were visible in living embryos, and also in well-fixed material, mainly at early stages. The limiting constrictions later flattened out and disappeared correlatively with the thickening of the differentiating 
mantle layer. This later pattern caused the myth about a merely transient existence of neuromeric subdivisions, which was denied experimentally by Marín and Puelles (1995) and Wingate and Lumsden (1996), who fate-mapped all overt rhombomeres, proving their permanent status. Von Kupffer (1906) and Ziehen (1906) summarized the early neuromeric results on all vertebrates at the turn of the twentieth century. It was determinant for the ulterior large-scale abandonment of neuromeric analysis that no functional application or cause was apparent at that time for a brain organizational principle based on embryonic transverse units. Functional application of this concept started only recently -e.g., Di Bonito et al., 2013, 2017 on rhombomere 4- and is still developing (work on segmental respiration and phonation circuitry, motor control, visuomotor reflexes). In contrast, the competing columnar model was based on indubitably successful functional analysis of adult nerve components (Gaskell, 1886, 1889; Johnston, 1902; Herrick, 1903). Later, such functional insight turned out to be premature and simplistic as regards the forebrain, and the columnar model proved weak on causal analysis.

As regards the forebrain (Fig. 2A), in which we now include the midbrain, diencephalon and hypothalamo-telencephalic complex (or secondary prosencephalon) (Fig. 2B), the most important neu-
A

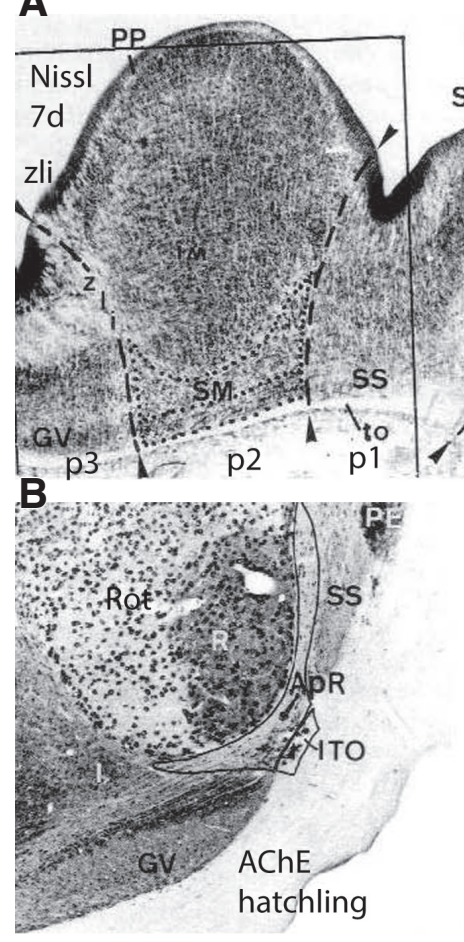

C

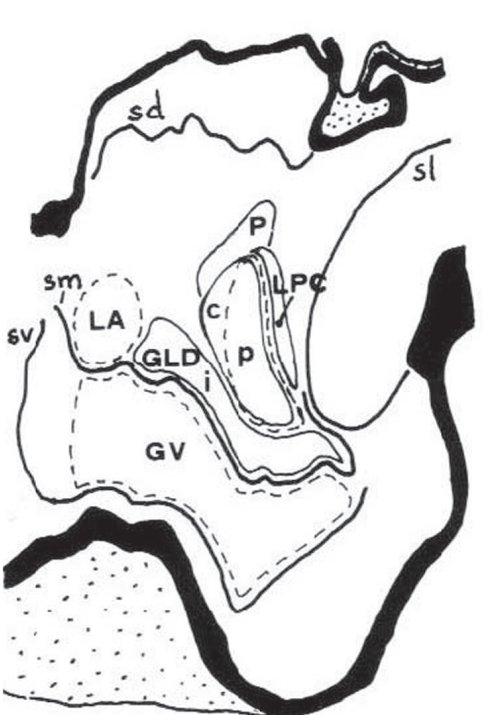

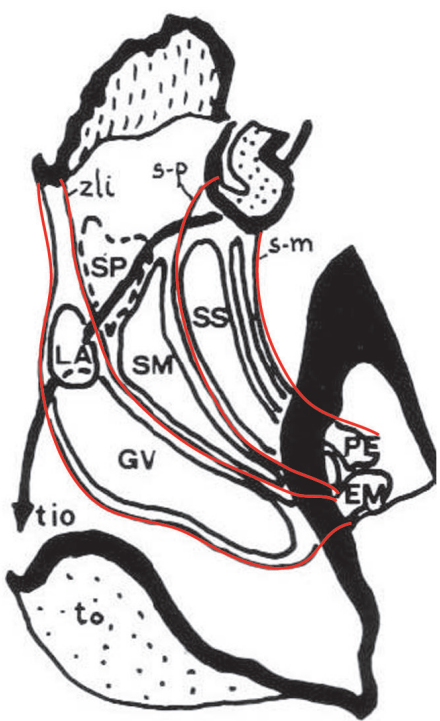

Fig. 6. Reproduction of some annotated images from Puelles et al. (1991) tracing an early thalamic population (SM) across subsequent developmental deformations, showing constancy of neuromeric limits. (I have added p1-p3 identifications and other details). The thick black contours in $(C, D)$ represent the roof (note the typical shape of the posterior commissure) and floor plates, as well as the acroterminal structures near the optic chiasma (to in D). This was our study of the permanence (with deformation) of neuromeric initial mantle formations throughout the embryonic period. (A) A Nisslstained horizontal section through a 7-day-old chick embryo (brain surface below; ventricle above; rostral to the left). The image is centred on the thalamus (p2; see the typical ovoid protrusion into the ventricle); at left we see its border with the prethalamus ( $\mathrm{p} 3$ ), that is, the zli (originally marked ' $z$ '); at right there is the pretectum ( 1 1). The two borders are marked with dash lines and arrowheads. Within the thalamus, one readilly detects a superficial stratum of larger neurons (SM), which caps the deeper ovoid mass of smaller elements. Autoradiographic analysis showed that this SM population is very precociously born, practically all before 2.5 days of incubation. It is clear that by 7 days the SM neurons are still neatly contained within the p2 neuromere. Note on the p3 side there appears a different prethalamic structure (GV or ventral geniculate nucleus), and on the p1 side there is again a cytoarchitecturally different population (SS, or superficial synencephalic nucleus). (B) A similar horizontal section in a chick hatchling, which was reacted for acetylcholinesterase (AChE). We again see at the center thalamus derivatives, including the nucleus rotundus (Rot; this is heterogeneous as regards AChE staining), capped superficially by the old SM, now much compressed between the prethalamic GV and the pretectal SS. Its cell population has decreased somewhat by cell death, but we distinguished a superficial portion we named ITO (n. interstitialis tractus optici) and a deeper component, the ApR (area perirotundica). A companion paper (Martínez et al., 1991) showed ITO and $A p R$ receive retinal projections and project to the optic tectum. The crucial point is that the primitive neuromeric boundaries are still exactly as seen at 7 days of incubation, and even earlier, when the cells are born strictly within p2. (C) A graphic reconstruction of these mantle elements at 9 days of incubation, obtained by recollecting relevant data from the same age from different papers of Kuhlenbeck (they are identified in the original figure legend); we thus have here the columnar version. Note the three limiting columnar diencephalic sulci (sd, sm, sv; dorsal, medius and ventral). The sd actually does not limit anything, being inside the habenular region. The sm practically coincides with the zli, being just rostral to it, as a remnant of the p3 ventricular cavity. The sv roughly separates prethalamus (p3) from hypothalamus. Rather than being longitudinal sulci as held by the columnar model, they are transversal landmarks that converge ventrally into the cephalic flexure (this was acknowledged by Kuhlenbeck, 1973). Kuhlenbeck thought that the whole area between sd and sm is dorsal thalamic; at this stage he recognizes already several nuclear differentiations within the region, notably those labelled LA, GLD and LPC, which is a complex with various parts. (D) A comparable reconstruction done by collecting Rendahl's data for a 10-dayold chick embryo, that is, a neuromeric interpretation of the same area. The reconstructions are indeed comparable in general. I retraced Rendahl's neuromeric boundaries in red, comparable to those in (A), and this reveals that the mass tagged LA actually lies in the prethalamus jointly with GV (both are retinorecipient grisea), or Kuhlenbeck confused it with the SP formation of Rendahl. The SM nucleus was identified as GLDi by Kuhlenbeck (same relation with GV), though the overlying SP formation is a better guess for the avian lateral geniculate nucleus homolog, in the light of ulterior hodologic data. Finally, the pretectal SS nucleus (also retinorecipient, comparable to the mammalian anterior pretectal nucleus) was misinterpreted as a dorsal thalamic LPC formation. In all cases, conserved neuromeric boundaries and neuromeric mantle derivatives were misinterpreted (with analogous reconstructions) as longitudinal entities. As suggested with $(A, B)$, the neuromeric domains suffer various degrees of compression at their superficial strata, the SM mass being the most compressed one. The conclusion is that neuromeric mantle domains get deformed, but they do not disappear. 
romeric studies were those of Palmgren (1921) on the midbrain and Rendahl (1924) on the diencephalon. More general studies were done by Bergquist and Källén (Bergquist, 1952; Bergquist and Källén,1953a,b; 1954, 1955; Källén, 1965), as well as by Wedin (1955) and Vaage (1969, 1973). These authors were influenced by the Swedish histologist Holmgren, who preconized analyzing brain organization on the basis of the cytoarchitecture found within the neural wall, rather than taking ventricular sulci as evidence for brain boundaries.

Palmgren's (1921) compared the developing midbrain in various vertebrates, including chick embryos; he was later disregarded by columnar scientists employing a different delimitation of the midbrain (Puelles, 2016), but his concept precedes our modern concept of the midbrain, divided into a major rostral mesomere and a small caudal mesomere (m1, m2; Figs. 2C; 8). Palmgren's midbrain limits with the isthmus caudally and with the pretectum rostrally (Figs.1E, 2C). His $\mathrm{m} 1$ and $\mathrm{m} 2$ transverse midbrain units were corroborated by Vaage $(1969,1973)$, and were recovered by Puelles and Martínez-de-la-Torre (1987) (m2; Figs. 7C, 8). Later, the small $\mathrm{m} 2$ mesomere was generalized to avian, mammalian and other vertebrate brains under the concept of preisthmus by the discovery of supporting gene expression patterns (HidalgoSánchez et al., 2005; Puelles, reference atlases for the Allen Developing Mouse Brain Atlas, www.developingmouse.brain-map. org; released 2009-2011; Puelles et al., 2012b, 2013; Puelles, 2013, 2017a). Hidalgo-Sánchez et al. (2005) first showed that there exist specific mantle derivatives of $\mathrm{m} 2$, which persist after experimental deletion of the whole hindbrain. Previous authors had erred in thinking there were none, $\mathrm{m} 2$ being assumed to be an atrophic neuromere (whatever that means). This development of the preisthmus concept, recognition in birds and mammals of the tectal gray (García-Calero et al., 2002) and the auditory torus semicircularis (Puelles et al., 1994; model corroborated by comparative genoarchitectonic work of Ayad, 2014), together with axial inversion experiments of Marín and Puelles (1994) and studies of early isthmo-mesencephalic epithelial fluidity (Puelles et al., 1996) expanded the modern concept of the fundamental organization of the avian and mammalian midbrain (Puelles et al., 2007, 2012b, 2017a).

Rendahl's (1924) thesis publication covered masterfully the developing chicken diencephalon. He first identified the transverse zona limitans intrathalamica (ZLI), and interpreted this neuroepithelial ridge as part of an interneuromeric boundary (Fig.5). The ZLI is now widely recognized as a transverse alar plate secondary organizer intercalated between prethalamus and thalamus (a.k.a.mid-diencephalic organizer, Puelles and Martínez, 2013), but was long disregarded by columnar authors (e.g., Kuhlenbeck, 1973; Swanson, 2003, 2012) or misinterpreted morphologically (Altman and Bayer, 1995). Rendahl identified three diencephalic neuromeres, called by him synencephalon, posterior parencephalon and anterior parencephalon, in caudo-rostral order; these are practically equivalent to our present diencephalic prosomeres dp1-dp3 minus the hypothalamus (Fig. 2C; 5,6,7C; p1-p3 in Fig.8). Rendahl (1924) admitted the columnar notion of the hypothalamus as a part of the diencephalon (ascribed to the anterior parencephalon, as in Figdor and Stern, 1994). However, his analysis of diencephalic neuromeres suggests a rostrally placed hypothalamus region, rather than a 'ventral' hypothalamic topography within the diencephalon (Fig. 5, compare Fig. 3). He also studied histogenetic development

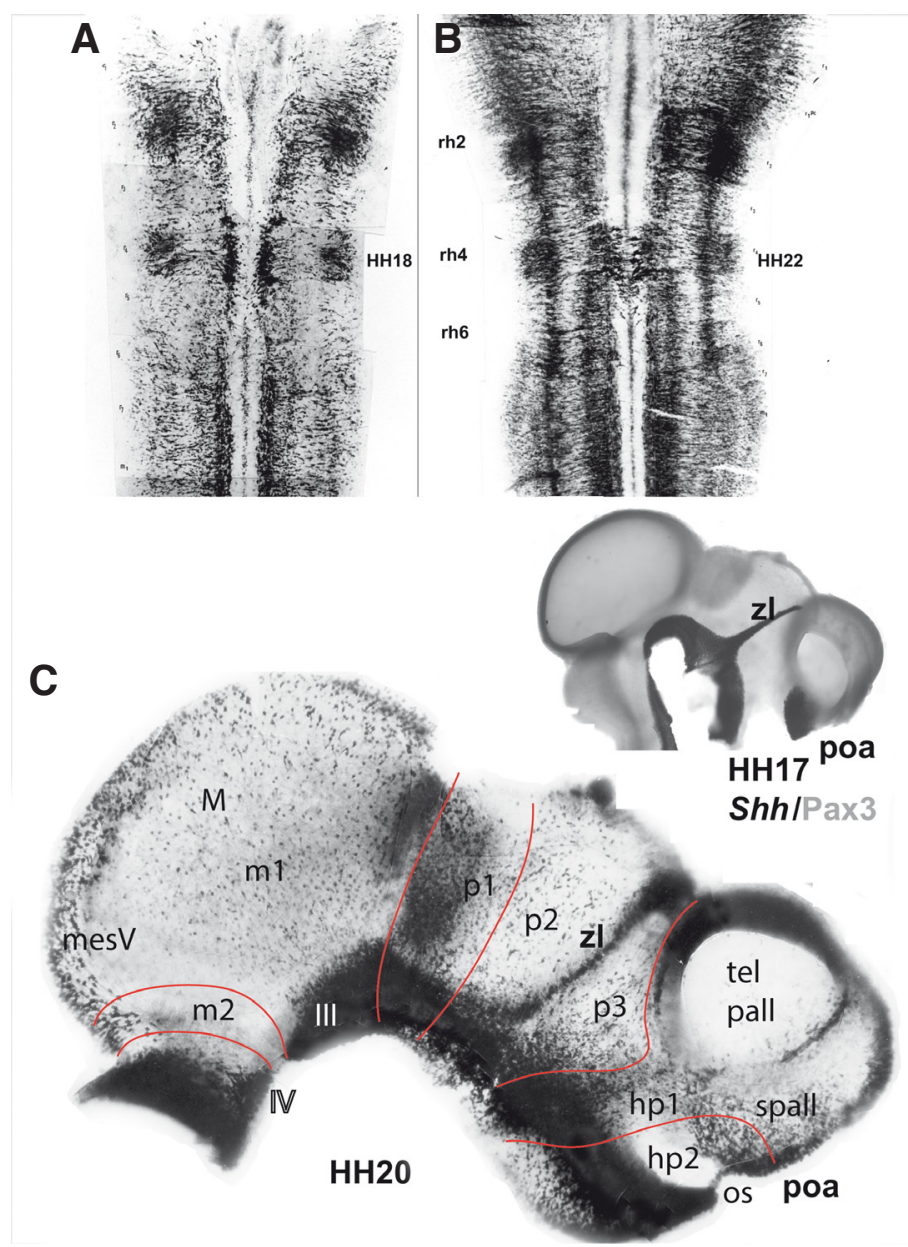

Fig. 7. Representative illustrations of dissected whole-mount acetylcholinesterase (AChE) forebrain preparates of chick embryos showing neuromeric heterochronic neurogenesis, partly published in Puelles et al. (1987b) and partly from the doctoral thesis of J.A.Amat (1986). (A,B) Wholemounts of fixed hindbrain specimens at stage $\mathrm{HH} 18$ and $\mathrm{HH} 22$, reacted by the Karnovski-Roots procedure overnight. The hindbrain preparates where then cleaned by hand at the microscope from all surrounding mesenchyme and meninges using sharpened tungsten needles; afterwards they were dehydrated, cleared, and flat-mounted before microphotography. Note more advanced neurogenesis in the paired rhombomeres $(r 2, r 4, r 6)$ and the distinct phenomena characterizing the basal versus the alar plates (and the floor plate, where a crossing of migrating cells is observed in $r 4$ (B), probably representing efferent vestibular cells). (C) This is a chick forebrain AChE wholemount at stage HH20; some neuromeric boundaries were traced in red. The basal plate domains through $m$ 1, p1-p3, hp1 and hp2 have finished their heterochronic program of neurogenesis and build now a seemingly continuous, massively populated basal plate domain comparable to that postulated by His (1895; our Fig. 4C). Note the basal plate does not extend into the telencephalon (a columnar tenet), but crosses the acroterminal rostral midline under the optic stalk (os), where it meets the contralateral basal plate. Basal elements include the oculomotor nucleus in 1 1 (III; and the $I V$ in the isthmus, barely seen). The $\mathrm{m} 2$ mesomere is nearly devoid of neurons at this stage, except some mesV cells. The alar domains show more growth in surface and sparse AChE cells. Some neuroepithelial loci are AChE-positive, such as the zona limitans (zl) and the epiphysis. Compare the inset image, at stage HH17, corresponding to Shh in situ (floor+basal plate+zona limitans) and Pax3 immunoreaction (part of alar pretectum above the alar-basal boundary). Note also Shh signal at the preoptic area (poa), which is also progressive with AChE-positive cells. 
of the diencephalic mantle, describing numerous avian diencephalic nuclei. Kappers, Huber and Crosby (1936) later commended the quality of Rendahl's (1924) study, but hardly followed his morphological conclusions (apart a few names), preferring the columnar approach. Fate-mapping work done by García-López et al. (2004, 2009), as well as AChE-histochemical or genoarchitectonic work done in our laboratory on the chicken and reptilian thalamus and pretectum (Martínez-de-la-Torre, 1985; Puelles et al., 1991; Martínez et al., 1991; Martínez-de-la-Torre et al., 2002; Ferrán et al., 2007, 2008, 2009; Merchán et al. 2011), was largely based on and consistent with Rendahl's analysis (Fig. 6). Rendahl's (1924) work is one of the best descriptive neuroembryological studies ever done.

Bergquist and Källén (Bergquist, 1952; Bergquist and Källén,1953a,b; 1954; 1955; Källén, 1965) examined several vertebrate embryo series in their neuromeric studies, but scarcely touched chick embryos. However, a good analysis of the developing turtle Lepidochelys olivacea forebrain illustrates the sauropsidian pattern from their perspective (Bergquist, 1953). Later, Källén examined the developing diencephalon and telencephalon in chick embryos (summary in Källén, 1965).

Vaage 's (1969) monographic work covers the issue of overt chicken neuromeres, with comments on all earlier literature on birds and other vertebrates. He reached the conclusion that the same number and pattern of neuromeres can be detected in all vertebrates. Against the thesis of Bergquist and Källén (1954) and Wedin (1955) that brain neuromeric phenomena proceed in three successive waves, Vaage concluded there is a single temporal series, a point now corroborated by much evidence. He offered a stage by stage analysis of neuromeric bulges, associated ventricular cavities, limiting constrictions, relationships to cranial nerve roots, and other landmarks. Moreover, he also produced an excellent description of the developing isthmic region in the chick (Vaage, 1973), leading to the identification and embryonic classification of adult isthmic nuclei. He correctly deduced that one classic 'isthmic' nucleus is actually mesencephalic in origin. This was corroborated with other methods (Puelles and Martínez-dela-Torre, 1987; Martínez-Hidalgo et al., 2005). This report also is a truly extraordinary descriptive neuroembryological study.

\section{The columnar model}

The columnar era started with Herrick's (1910) report of forebrain subdivisions in amphibians and reptiles. Due to the poor resolution of cytoarchitectonic methods available at the time, particularly when applied to anamniote brains that show scarce neuronal migration into the mantle, he used sulci visible at the neural ventricular surface as indicators of architectonic subdivisions. This approach had been successful in the hindbrain in the studies of Gaskell (1886, 1889), Johnston (1902), and Herrick (1903), where three brainstem longitudinal sulci separate four columns of neurons related to functionally distinct cranial nerve components. Herrick (1910) examined whether such columns extended into the forebrain, aiming to extrapolate there the functional properties of the hindbrain. He did find three sulci that divided the diencephalon and hypothalamus territory into four regions (Fig. 3A). However, morphologic analysis of his diencephalic sulci in context with the longitudinal zones of His (Fig. 4) indicates they course orthogonally relative to the sulcus limitans and are accordingly transverse. Nevertheless, Herrick (1910) pragmatically passed to describe his diencephalic columns and sulci as 'longitudinal', without presenting any developmental or anatomic fundament for a new axis, and without discussing or even mentioning having changed the classic length axis of His. Only in his last work (Herrick, 1948), he commented that "...this change was controversial ..., but convenient", showing he did not apply it unwittingly. The columnar (longitudinal) model of the forebrain was thus born in adult amphibians as a preconceived notion based on transverse diencephalic sulci that simply passed to be regarded as longitudinal according to an undefined and unsupported new length axis that negates the cephalic flexure and finishes in the telencephalon (this point is discussed and illustrated in Puelles et al., 2007; Text Figs. 4-6). Importantly, neither Herrick (1910, 1933) nor his immediate followers (e.g., Kuhlenbeck, 1927, 1935, 1936, 1973) examined the early patterns of neurogenesis (the axial basal plate domain of His was defined by precocious neurogenesis and differentiation; Fig. 4 B,C). Recently, Swanson (2003, 2012) drew schemata postulating that the basal plate ends in the telencephalon, but did not show any evidence for this, nor discussed contrary published evidence; compare Fig. 7C). Columnar-inspired works reporting neurofibrillary development in chick embryos (e.g., Windle and Austin, 1936, Lyser, 1966, Bösel, 1974) did not comment about this aspect, nor considered neuromeric interpretation of their results, irrespective of the earlier neuromeric neurofibrillar descriptions of Tello $(1923,1934)$.

The concept of neuromeres was clearly left aside in the columnar model of the brain, assuming these were artefactual or transient phenomena devoid of functional importance (Streeter, 1933; Kuhlenbeck, 1973). Functional pregnancy became the predominant guide of American neuroanatomic analysis of brain organization during the two world wars and the ulterior post-worldwar period, in which many European schools decayed. It soon became clear that there were more interesting functions to ascribe to the forebrain than mere repetition of the hindbrain functional specializations, thus rendering obsolete Herrick's (1910) primary aim. However, the columnar model was by then very strongly implemented as the predominant morphologic paradigm in the field of neuroanatomy. Its undiscussed length axis became an unmentioned dogma, an apparent truth known by everybody, as was the supposed longitudinal status of the four diencephalic columns separated by sulci (Fig. 3B). This tendentious and preconceived fundamental convention caused no problems as long as causal explanation of the assumed brain organization was not required (i.e., connectivity and physiological studies seemed congenial with the columnar model, but a recapitulation is needed to see what was left behind). This changed when the expression patterns and functions of developmental genes started to be investigated and patterning analysis began.

The main columnar analysis of brain organization performed on birds was that of Kuhlenbeck (1927, 1935, 1936, 1937, 1939). This work centred on the forebrain was later reexamined in Kuhlenbeck's treatise $(1973,1975)$, but left unchanged. This erudite author accepted without criticism the occult axial dogma of the columnar model. In contrast to Herrick, though, he insisted on a purely formanalytic approach (delimitations based on relative position within a Bauplan), and considered premature any functional speculations. Unfortunately, Herrick's (1910) methodology of mapping ventricular sulci as indirect landmarks of boundaries of neuronal groups led him to errors of interpretation. We realize now in retrospect that genomic and epigenetic mechanisms cannot 
codify ventricular sulci, which are at best variable tertiary mechanic consequences of brain wall morphogenesis. The pattern of sulci thus changes even within a species and is therefore a bad basis for comparative neuromorphological analysis. Kuhlenbeck was the only author among the believers in the columnar model that acknowledged the early existence of neuromeres (Kuhlenbeck, 1935, 1973). However, he concluded that these were transient early phenomena, and held that the subsequent development of the four longitudinal diencephalic columns overlaid the disappearing neuromeric boundaries, leaving no adult counterparts (Figs. 3, 6C; Kuhlenbeck, 1935,1936, 1937, 1939, 1973).

We explicitly tested this last hypothesis (Puelles et al., 1991), studying the development of an early avian thalamic cell group the superficial magnocellular nucleus of Rendahl (1924)-, whose birthdates are so precocious that its neurons are all present before the neuromeric constrictions disappear (Fig. 6). We showed that this cell mass and several others near it in dp1-dp3 can be followed step by step as discrete cytoarchitectonic entities, remaining limited by neuromeric boundaries during the period in which they should be effaced by developing columns (Fig.6 A-D). Such populations finally represent functional targets of retinal afferences and the source of projections to the pretectum and optic tectum (Puelles et al. 1991; Martínez etal., 1991a). These results first negated the myth of the homogeneity of Herrick's diencephalic longitudinal columns, as well as the myth of columnar occlusion of earlier neuromeric pattern, both defended by Kuhlenbeck (1973). The discreteness of the superficial magnocellular nucleus was later corroborated by its selective expression of the gene Nkx2.2 (Martínez-de-la-Torre et al., 2002), and fate-mapping quail-chick grafting experiments illustrated the distinct and permanent fates of the three diencephalic neuromeres (García-López et al., 2004, 2009).

Kuhlenbeck (1939) also attempted a developmental columnar analysis of the chicken pretectum, which in his interpretation falls in part in the epithalamic and thalamic diencephalic columns and in part in the midbrain (Fig. 3B, compare Fig. 8). Columnar authors always had problems interpreting the pretectum of vertebrates. Contrarily, it is easily understood as an alar part of an independent neuromere (Figs. 5,7,8). Recently, we studied early genoarchitectonic delimitation and ulterior development of the avian pretectum, corroborating its permanent molecularly-specified neuromeric boundaries. We also first described its tripartiteAP alar regionalization (Ferrán et al., 2007, 2008, 2009; Merchán et al., 2011). These results expanded the bipartite AP alar pretectal division previously suggested by Rendahl (1924). A tripartite genoarchitectonic alar pretectal pattern has since been corroborated with gene markers as well in the mouse (Ferran et al., 2008; work in progress) and in the frog (Morona et al., 2011), and the same pattern clearly exists in reptiles (histochemical comparative AChE analysis of Martínezde-la-Torre, 1985).

\section{The second wave of neuromeric studies}

Referring to avian studies, and defining the second wave of neuromeric studies as implying some sort of novel molecular approach, our own study of acetylcholinesterase activity in chicken diencephalic neuromeres (Puelles et al., 1987b) represents a modest starting point. Its genesis may be of interest, showing how a non-committed columnar scientist became a believer in neuromeres. We examined topographic whole-mount mappings of acetylcholinesterase-reactive newborn neurons (e.g., Fig. 7C), concluding that the observed neurogenesis patterns were supportive of a neuromeric interpretation sensu Rendahl (1924). This work employed selective demonstration of individual AChE-positive postmitotic neurons against the AChE-negative progenitor and glial cells. Previous Golgi studies on patterns of differentiation of diencephalic neurons, continuing work done on the optic tectum (Puelles and Bendala, 1978; Bendala, 1978; Zabala, 1978), had shown hidden transverse boundaries crossing the theoretically

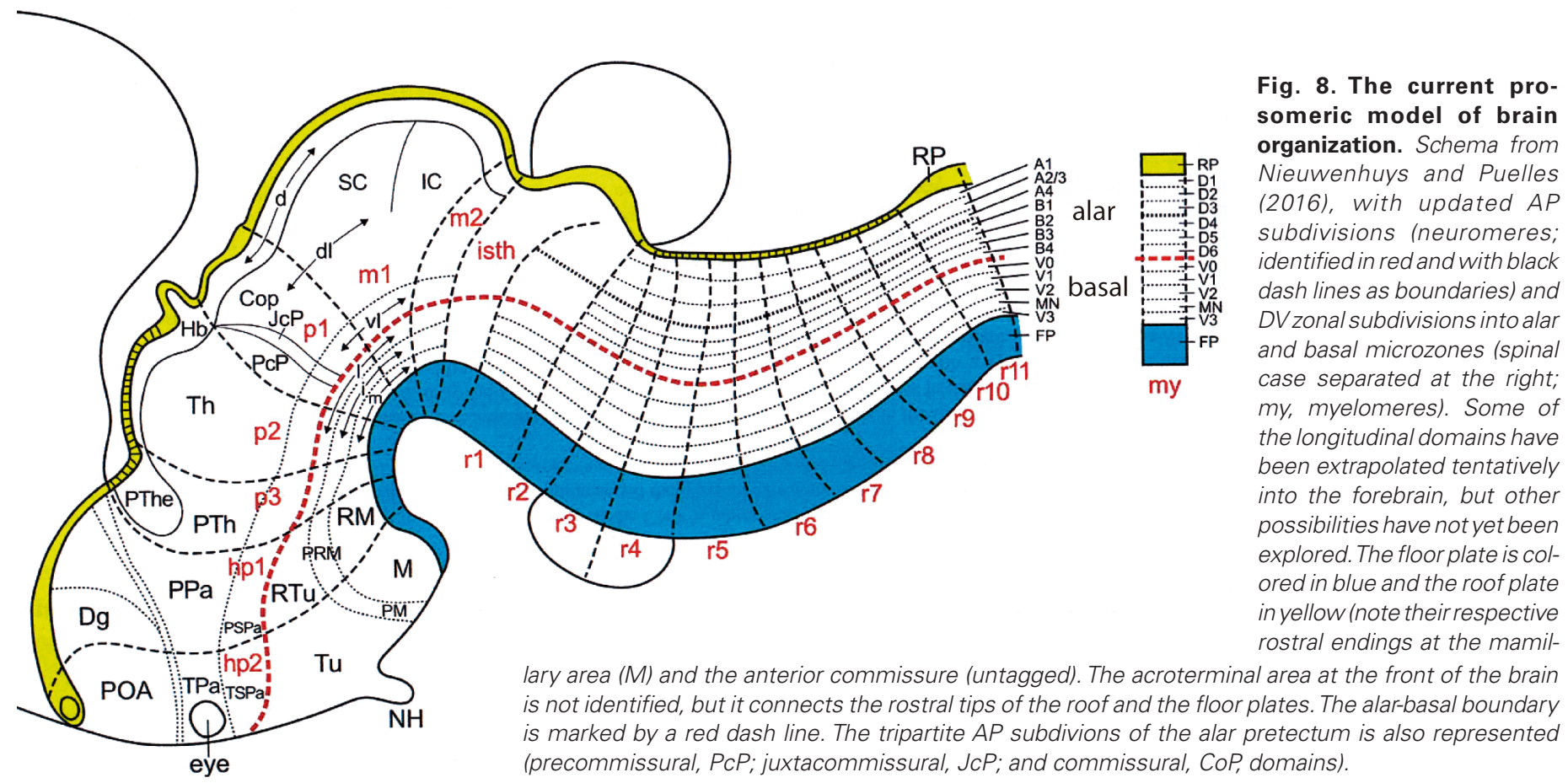


homogeneous longitudinal diencephalic columns, separating unexpected blocks with different cell typology at early stages. These data produced our first notion that something was wrong with the columnar theory of the diencephalon, which made one to expect homogeneity of cell types. During a conversation with J.Reperant, the French expert on avian visual centres, he recommended reading Rendahl's (1924) developmental monograph. I thus stumbled unexpectedly upon neuromeric studies, of which I was not previously aware at all. One obscure paper led to the next, and study of this literature showed that chicken diencephalic Golgi patterns were definitely consistent with a neuromeric interpretation sensu Rendahl (1924). However, the Golgi data were thought unsuitable to publish on this idea in a non-receptive columnar scenario. I had started using wholemount AChE staining in a parallel project on the migration across the midline of oculomotor neuroblasts (Puelles et al. 1975, Puelles and Privat, 1977, Puelles, 1978). I was surprised to see in the cleared whole-mounts well-delimited groups of postmitotic AChE-positive neurons throughout the early hypothalamus, diencephalon, midbrain and hindbrain (Fig. 7 A-C), whose spatial pattern and heterochronic sequence of appearance also seemed to contradict columnar interpretations, but agreed with the neuromeric descriptions of Rendahl (1924). I realized that histochemical evidence on heterochronic neurogenesis in a neuromeric organization of the forebrain-midbrain region was going to be much easier to pass through the peer review system than a neuromeric analysis of Golgi data. We thus concentrated on the AChE whole-mount histochemical analysis (Fig.7A-C; Puelles etal., 1987b; Amat, 1986). This was after American neuromorphologists had officially pronounced neuromeres dead (e.g., Streeter, 1933; Kuhlenbeck, 1973), but luckily was also briefly before they were reborn again thanks to experimental results on clonal restriction (Lumsden and Keynes, 1989; Fraser et al., 1990) and gene expression evidence (Gaunt et al., 1986; Murphy et al., 1989; Wilkinson et al., 1989a,b; Sundin and Eichele, 1990; Krumlauf et al., 1993), which lent renewed life to neuromeric theory. Our publication was complementary to this new set of reports, in that we concentrated on the hypothalamus, diencephalon and midbrain, whereas the British colleagues examined mainly hindbrain rhombomeres.

While attending the Society for Neuroscience meeting in the States in 1991, I met John L.R. Rubenstein, who invited me to discussions in his lab. This was the prelude of our strong, varied and durable collaboration over the following years until the present, leading to the joint proposal and ulterior updating of the prosomeric model on the basis of a variety of gene expression patterns interpreted according to neuromeric tenets (e.g., Puelles and Rubenstein, 1993, 2003, 2015; Rubenstein et al., 1994, 1998; Puelles et al., 2000, 2004, 2012a; Shimamura et al., 1995, 1997; Puelles, 1995, Rubenstein et al., 1998, and Puelles et al., 2000 contained chick embryo material). After implementing in situ hybridization procedures in our own laboratory we performed many comparative gene mapping studies on chick and mouse embryos, which eventually provided added molecular evidence on brain organization viewpoints.

\section{The midbrain-hindbrain boundary}

Experimental embryologic analysis of the avian brain was boosted by the quail-chick grafting procedure created by Le Douarin (LeDouarin, 1969; Le Douarin and Barq, 1969). This author contributed important studies on the avian neural crest (e.g., Le Douarin, 1999; Le Douarin and Dupin, 2012). As regards the brain, she dedicated attention to the caudal terminal region of the spinal cord (e.g., Catala et al., 1995), and performed fate-mapping studies on the early chicken neural plate (Couly and Le Douarin, 1987) as well as on hindbrain derivatives studied in dorsoventral grafts of varying sizes (Tan and Le Douarin, 1991; neuromeres were not considered). The neural plate fate map was rather simple, compared to those of Fernández-Garre et al. (2002) and Sánchez-Arrones et al. $(2009,2015)$. It probably cannot be said that Le Douarin contributed significantly to the analysis of brain organization. Not every good experimental embryologic study contributes to notions of brain organization, because there are other targets of scientific curiosity. This grafting approach was imported to our laboratory by my pupil S. Martínez (thesis Univ.Murcia 1987), who learned it during his postdoctoral stage with R.M. Alvarado-Mallart at the INSERM U106, Paris.

Martínez and Alvarado-Mallart discovered an apparently caudal mesencephalic partial origin of the rostral vermal cerebellum (Martínez and Alvarado-Mallart, 1989, 1990;Alvarado-Mallart et al., 1990). This (false) impression was corrected later by demonstrating fluidity (i.e., lack of morphologic stability) of the early vesicular midbrain-hindbrain boundary, as opposed to the fixed caudal Otx2 molecular limit of the midbrain (Puelles et al., 1996; Millet et al., 1996; Hidalgo-Sánchez et al., 1999). More importantly, Martínez and Alvarado-Mallart found the first evidence for a cerebellar- and caudal mesencephalic inducing capacity of what became known as the isthmic organizer (Martínez et al., 1991b; Alvarado-Mallart, 1993; see also Marín and Puelles, 1994). Other relevant experimental work from that laboratory included Bally-Cuif et al. (1992; gene mapping), Alvarez-Otero et al. (1993; a detailed cerebellar fate map), Wassef et al. (1993: cerebellar regionalization), Millet et al. (1996; Otx2 as marker of the caudal midbrain boundary), Hallonet and Alvarado-Mallart (1997; again on the cerebellum), Alvarado-Mallart, (2005), and Hidalgo-Sánchez et al. (2005b). Work on the isthmic organizer was subsequently continued by Martínez's own lab in Murcia (Garda et al., 2001; Martínez, 2001; Gimeno et al., 2002, 2003; Echevarría et al., 2005), and also sparked numerous international studies in mice and zebrafish. Collectively, all this work definitely established the role as isthmic morphogen of the fibroblast growth factor 8 (FGF8) and threw light on a number of other molecular details upstream and downstream of this organizer signal (see Crossley et al., 1996, 2001; Martínez et al., 1999). Some of this work included collaboration of Martínez with G.R.Martin in S.Francisco (Wassarman et al., 1997; Chi et al., 2003; Basson et al., 2008). In parallel, additional relevant work appeared on the ectopic inducing properties of the isthmic organizer in the diencephalon, which also illuminated and supported the neuromeric structure of the diencephalon (Bloch-Gallego et al., 1996; Martínez et al., 1999; Hidalgo-Sánchez et al., 1999; Hidalgo-Sánchez and Alvarado-Mallart, 2002; Vieira et al., 2006, 2010; Crespo-Enriquez et al., 2012).

\section{Rhombomeres and prosomeres}

Lumsden and colleagues performed over the years numerous high quality studies on rhombomeres r2-r6 (e.g., Lumsden and Keynes, 1989; Fraser et al., 1990; Lumsden, 1990, 1991; Heyman et al., 1993, 1995; blue domain in Fig.2C). These hardly contributed 
new notions on brain organization, since these units were known to Orr (1887) and all neuromerists. Importantly, Lumsden did not accept the theoretic notion of a segmental AP organization of the entire brain inspired in the rhombomeres, as postulated by our group in the prosomeric model (Fig. 2C). Puelles and Rubenstein (2003) argued against Lumsden that why should the very restrictive properties of interrhombomeric boundaries (e.g., clonal restriction) dictate how all interneuromeric boundaries in the brain should be, thus deciding which developmental units are metameric, as was later repeatedly defended by the British group (e.g., Kiecker and Lumsden, 2005, 2009, 2012; Graham et al., 2014)? We hold that metamerism must reside in repeated fundamental organization of the internal structure of neuromeres, and not their boundaries. We refer in this regard to the DV pattern of longitudinal zonal elements (Puelles and Rubenstein, 2003; Puelles, 2013; see also Nieuwenhuys and Puelles, 2016; Fig.8). Limits should be treated as consequences of primary patterns, emerging because differential molecular organization appears first, not the other way around. Relevantly, if two odd-numbered or pair-numbered rhombomeres are experimentally put together, no limit emerges.

In reaction to this issue, and pondering on the possible existence of hidden (cryptic) rhombomeres in the medullary hindbrain, we reexamined first by means of experimental quail-chick fate mapping the overt and potential cryptic rhombomeres (Marín and Puelles, 1995; Cambronero and Puelles, 2000), and then rechecked by expression mapping of Hox gene family elements any selective codes within the segmented and apparently nonsegmented hindbrain regions of chick and mouse embryos (Marín et al., 2008; Tomás-Roca et al., 2016). This revealed the existence of crypto-rhombomeres r7-r11 (Figs. 2C; 8), which are sharply distinguished by differential expression of Hox gene families 4-8 (while overt rhombomeres are coded by Hox families 1-3). We also studied the prepontine hindbrain area, supposedly occupied just by Lumsden's ' $r 1$ ' neuromere, which is a domain about three times bigger than any normal rhombomere. Studies in chick or mouse had suggested a strictly isthmic neuromere ( $\mathrm{r} 0$ ) and rostral and caudal parts of the rest of $r 1$ (Vaage, 1973; Aroca and Puelles, 2005; Aroca et al., 2006; Lorente-Cánovas et al., 2012; Alonso et al., 2012). Recently, spatially restricted neural progeny of the postulated isthmic segment was studied (Watson et al., 2017). As a whole, these hindbrain studies suggest that the avian and mouse hindbrain is organized in 13 AP neuromeric units, which include $\mathrm{r} 0$ (isthmus), r1r (rostral), r1c (caudal) and r7-r11 among cryptorhombomeres, as well as the classic overt rhombomeres r2-r6 (Figs. $2 \mathrm{C}, 8)$. We hold that this more elaborate concept of hindbrain AP configuration, enriched as well with the new microzonal concept of longitudinal DV brain organization (Fig.8), should help significantly ongoing neurobiological research.

Eventually, Lumsden entered the field of chicken diencephalic prosomere studies, where he produced a series of reports based on chick embryos (e.g., Larsen et al., 2001; Zeltser et al., 2001; Kiecker and Lumsden, 2004, 2005, 2009, 2012; Scholpp et al.,

\section{A}

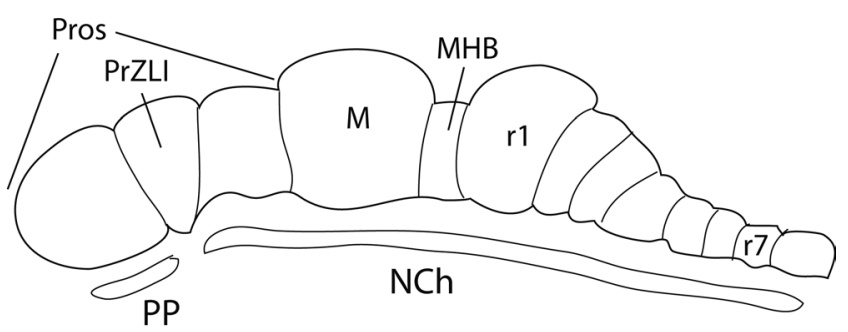

B

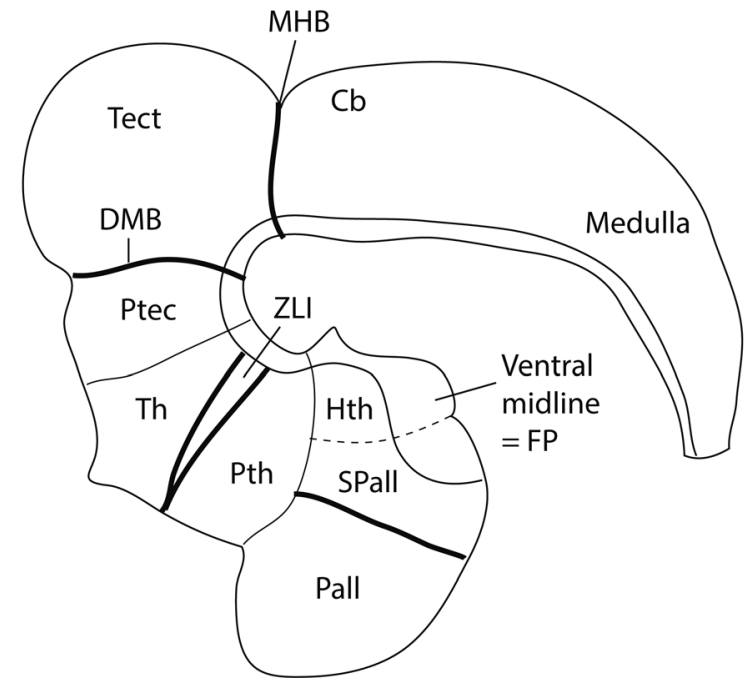

Fig. 9. Aberrant 'clonal' forebrain model of Lumsden lacking a basal plate. (A,B) Redrawn versions of Kiecker and Lumsden's (2005) Figs. 1a,b. (A) An early hypothetic stage in which the prospective ZLI (PrZLI) and isthmic (MHB) organizers are postulated speculatively to be present in the shape of intercalated neuromeres. These would atrophy or compact secondarily, generating the corresponding secondary organizers shown in (B). (B) An illustration of what I term the 'brain clonal restriction model' of chick forebrain organization, unnamed by its authors; it is based on sole acceptance as boundaries of limits believed to exhibit clonal restriction (thick black lines); other boundaries traced with thin lines are not accepted as neuromeric. One guesses that the thalamo-pretectal limit is generated interactively by signalling from neighboring 'true' boundaries, but the diencephalo-hypothalamic limit seems arbitrary (though based on the prosomeric model). This forebrain schema surprises us by lacking a basal plate altogether (or an alar-basal distinction), so that the transverse organizers are presented as reaching from roof to floor of the neural tube. This is fabricated and inconsistent with much recorded evidence (e.g., Fig. 7C and inset). Moreover, the schema shows what these authors think about the hypothalamo-telencephalic region, which was divided into two hypothalamo-telencephalic prosomeres -hp1, hp2 (Fig. 8)- by Puelles et al. (2012a), Martínez et al. (2012), Puelles (2013), and Puelles and Rubenstein (2015). The insights for this concept came from chick hypothalamic gene expression data obtained in the thesis of Bardet (2007) at the university of Murcia. The hypothalamus of Kiecker and Lumsden $(2005,2009)$ is wrongly reduced to a small ventral region, ventrally to the telencephalic subpallium, which takes over what is usually regarded alar hypothalamus. There is no alar hypothalamus, and thus no place for the eye evagination, so that important parts of the hypothalamus are missing. The telencephalon appears divided by a longitudinal clonal boundary into pallial and subpallial regions. This feature is inconsistent with the fate mapping experimental data of Cobos et al. (2001), García-López et al. (2009), and Pombero and Martínez (2009), which uniformly concluded that the prospective subpallium lies rostral to the pallium (see also Sánchez-Arrones et al., 2009, 2012, and our Fig. 1 D,E). The purported dorsal and ventral relative positions of pallium and subpallium is a columnar tenet, due to the arbitrary ending of the implied columnar length axis inside the telencephalon (but in that model the hypothalamus would lie caudally to the telencephalon). Here Kiecker and Lumsden (2005) apparently have not understood the difference between the two discrepant neuromeric and columnar axial definitions, and have used the neuromeric axis while adopting the conventional columnar pallio-subpallial topography. 
2006, 2007; Scholpp and Lumsden, 2010; Peukert et al., 2011). Some of this is excellent work that contributed to clarify the role of the ZLI as a secondary organizer (Kiecker et al., 2004; Scholpp et al., 2006, 2007; Guinazu et al., 2007; Scholpp and Lumsden, 2010). I regard other studies in this list, particularly Larsen et al. (2001) and Zeltser et al. (2001), as well as the Kiecker and Lumsden $(2005,2009,2012)$ reviews as conflictive and non-convincing, mainly due to lack of documentation of where label injections was made and tendentious discussion that disregards other evidence or interpretation possibilities (text of Fig.9). One thesis of these studies is that there exists a primordial neuromere (Fig. 9A), which soon transforms by atrophy or compaction (not demonstrated apart of gene expression changes) into the linear ZLI organizer, which patterns prethalamic and thalamic areas (Fig.9B). This idea has given rise to what can be named an aberrant 'brain clonal restriction model' which has some features of a neuromeric model (e.g., the axis) and others of the columnar model (see text of Fig.9B on telencephalo-hypothalamic areas), but postulates controversial neuromeric compaction at the ZLI and a primordial isthmic neuromere. Most controversially, it eliminates without discussion the whole forebrain basal plate, inconsistently with García-Calero et al. (2008) and García-López et al. (2004, 2009) fate maps (Fig. 9 $A, B)$. This aberrant feature serves for preconceived and illusory extension of the ZLI and other potential organizers down to the floor plate (in contrast, see Fig. 7C and inset). Critical comments on the Lumsden ZLI topic in the light of a different theory of the generation of the ZLI, without the need to assume any fantastic compaction, were already advanced (Puelles and Martínez, 2013; Martínez-Ferre et al., 2013).

As regards the midbrain, whose mesomeres are actually also midbrain prosomeres (Fig. 2A), Lumsden admits the transverse boundaries of Palmgren (1921) but no internal AP subdivision, as well as no basal plate (Fig. 9B). He separately defends the concept of a singular 'arcuate' banded midbrain region with distinct gene expressions (Agarwala et al., 2001; Agarwala and Ragsdale, 2002; Sanders et al., 2002) as some sort of novel 'arched' morphologic organization. I interprete these midbrain arcs as caused by axial bending of the topologically longitudinal alar and basal zones at the cephalic flexure. A secondarily bent longitudinal zone continues being longitudinal.

\section{Acknowledgment}

Supported by SENECA contract 19904/ GERM/15 (Autonomous Community of Murcia, Spain).

\section{References}

AGARWALA S, RAGSDALE CW (2002). A role for midbrain arcs in nucleogenesis. Development 129: 5779-5788.

AGARWALA S, SANDERS TA, RAGSDALE CW (2001). Sonic hedgehog control of size and shape in midbrain pattern formation. Science 291: 2147-2150.

ALONSO A, MERCHÁN P, SANDOVAL JE, SÁNCHEZ-ARRONES L, GARCIACAZORLAA, ARTUCH R, FERRÁN JL, MARTÍNEZ-DE-LA-TORRE M, PUELLES $L$ (2012). Development of the serotonergic cells in murine raphe nuclei and their relations with rhombomeric domains. Brain Struct Funct 218: 1229-1277.

ALTMAN JA, BAYER SA (1995). Atlas of prenatal rat brain development. Boca Ratón: CRC.

ALVARADO-MALLARTRM (1993). Fate and potentialities of the avian mesencephalic/ metencephalic neuroepithelium. J Neurobiol 24: 1341-1355.

ALVARADO-MALLART RM (2005). The chick/quail transplantation model: discovery of the isthmic organizer center. Brain Res Brain Res Rev 49: 109-113.
ALVARADO-MALLART RM, MARTINEZ S, LANCE-JONES CC (1990). Pluripotentiality of the 2-day-old avian germinative neuroepithelium. Dev Biol 139: 75-88.

ALVAREZ OTERO R, SOTELO C, ALVARADO-MALLART RM (1993). Chick/quail chimeras with partial cerebellar grafts: an analysis of the origin and migration of cerebellar cells. J Comp Neurol 333: 597-615.

AMAT SUÁREZ JA (1986). Compartimentación y dinámica neurogenética del tubo neural del embrión de pollo. Manifestación heterocrónica del plan estructural del neuroeje. PhD thesis in Medicine. Univ. of Murcia (Spain).

ANDREAE LC, PEUKERT D, LUMSDEN A, GILTHORPE JD (2007). Analysis of Lrrn1 expression and its relationship to neuromeric boundaries during chick neural development. Neural Dev. 2: 22.

AROCA P, PUELLES L (2005). Postulated boundaries and differential fate in the developing rostral hindbrain. Brain Res Rev 49: 179-190.

AROCA P, LORENTE-CÁNOVAS B, MATEOS FR, PUELLES L (2006). Locus coeruleus neurons originate in alar rhombomere 1 and migrate into the basal plate: studies in chick and mouse embryos. J Comp Neurol 496: 802-818.

AYAD A (2014). Genoarquitectura comparada del mesencéfalo alar en el ratón y el pollo. PhD thesis in Biology (Neuroscience program). Univ. of Murcia (Spain).

BAER K E VON (1828). Über die Entwicklungsgeschichte der Thiere. Beobachtung und Reflexion. Königsberg: Bornträger.

BALLY-CUIF L, ALVARADO-MALLART RM, DARNELL DK, WASSEF M (1992). Relationship between Wnt-1 and En-2 expression domains during early development of normal and ectopic met-mesencephalon. Development 115: 999-1009.

BARDET SM (2007). Organización morfológica y citogenética del hipotálamo del pollo sobre base de mapas moleculares. PhD in Biology (Neuroscience Program). Univ. of Murcia (Spain).

BASSON MA, ECHEVARRIA D, AHN CP, SUDAROV A, JOYNER AL, MASON IJ, MARTINEZS, MARTIN GR (2008). Specific regions within the embryonic midbrain and cerebellum require different levels of FGF signaling during development. Development 135: 889-898.

BENDALA GARCÍA MC (1978). Desarrollo de la morfología neuronal en el lóbulo óptico del embrión de pollo. Estudio con el método de Golgi. PhD thesis in Sciences. Univ. of Sevilla (Spain).

BERGQUIST H (1952). Studies on the cerebral tube in vertebrates. The neuromeres. Acta Zool 33: 57-303.

BERGQUIST H (1953). On the development of diencephalic nuclei and certain mesencephalic relations in Lepidochelys olivacea and other reptiles. Acta Zool 34: 155-190.

BERGQUIST H, KÄLLÉN B (1953a). Studies on the topography of the migration areas in the vertebrate brain. Acta Anat 17: 353-369.

BERGQUIST H, KÄLLÉN B (1953b). On the development of neuromeres to migration areas in the vertebrate cerebral tube. Acta Anat. 18: 65-73.

BERGQUIST H, KÄLLÉN B (1954). Notes on the early histogenesis and morphogenesis of the central nervous system in vertebrates. J Comp Neurol 100: 627-659.

BERGQUIST H, KÄLLÉN B (1955). The archencephalic neuromery in Ambystoma punctatum. An experimental study. Acta Anat 24: 208-214.

BLOCH-GALLEGO E, MILLETS, ALVARADO-MALLARTRM (1996). Further observations on the susceptibility of diencephalic prosomeres to $E n-2$ induction and on the resulting histogenetic capabilities. Mech Dev 58: 51-63.

BÖSEL R (1974). Das erste Nervenfaserwachstum im Gehirn von Hühnerembryonen bis zum Stadium HH17. J Hirnforsch 15: 23-48.

CAMBRONERO F, PUELLES L (2000). Rostrocaudal nuclear relationships in the avian medulla oblongata: Fate-map with quail-chick chimeras. J Comp Neurol 427: 522-545.

CATALAM, TEILLET MA, LE DOUARIN NM (1995). Organization and development of the tail bud analyzed with the quail-chick chimaera system. Mech Dev 51:51-65.

CHI CL, MARTINEZ S, WURST W, MARTIN GR (2003). The isthmic organizer signal FGF8 is required for cell survival in the prospective midbrain and cerebellum. Development 130: 2633-4264.

COBOS I, SHIMAMURA K, RUBENSTEIN JLR, MARTÍNEZ S, PUELLES L (2001) Fate map of the avian anterior forebrain at the 4 somite stage, based on the analysis of quail-chick chimeras. Dev Biol 239: 46-67.

COGGESHALL RE (1964). Study of diencephalic development in the albino rat. $J$ Comp Neurol 122: 241-270.

COULY GF, LE DOUARIN NM (1987). Mapping of the early neural primordium in quail- 
chick chimeras. II. The prosencephalic neural plate and neural folds: implications for the genesis of cephalic human congenital abnormalities. Dev Biol120: 198-214.

CRESPO-ENRIQUEZI, PARTANEN J, MARTINEZ S, ECHEVARRIAD (2012). Fgf8related secondary organizers exert different polarizing planar instructions along the mouse anterior neural tube. PLoS One. 7: e39977.

CROSSLEY PH, MARTINEZ S, MARTIN GR (1996). Midbrain development induced by FGF8 in the chick embryo. Nature 380: 66-68.

CROSSLEY PH, MARTINEZ S, OHKUBO Y, RUBENSTEIN JL (2001). Coordinate expression of Fgf8, Otx2, Bmp4, and Shh in the rostral prosencephalon during development of the telencephalic and optic vesicles. Neuroscience 108: 183-206.

DI BONITO M, NARITA Y, AVALLONE B, SEQUINO L, MANCUSO M, ANDOLFI G, FRANZÉ AM, PUELLES L, RIJLI FM, STUDER M (2013). Assembly of the auditory circuitry by a Hox genetic network in the mouse brainstem. PLoS Genetics 9: e1003249.

DIBONITOM.A., STUDERM., AND PUELLESL(2017). Nuclear derivatives and axonal projections of mouse rhombomere 4 studied by means of Hoxb1-Cre-YFP expression. Brain Struct. Funct. 222: 3509. https://doi.org/10.1007/s00429-017-1416-0

ECHEVARRIA D, BELO JA, MARTINEZS (2005a). Modulation of Fgf8 activity during vertebrate brain development. Brain Res Brain Res Rev 49: 150-157.

ECHEVARRIA D, MARTINEZ S, MARQUES S, LUCAS-TEIXEIRA V, BELO JA (2005b). Mkp3 is a negative feedback modulator of Fgf8 signaling in the mammalian isthmic organizer. Dev Biol 277: 114-128.

FERNÁNDEZ-GARRE P, RODRÍGUEZ-GALLARDO L, ALVAREZ IS, PUELLES $L$ (2002). A neural plate fate map at stage $\mathrm{HH} 4$ in the chick: methodology and preliminary data. Brain Res Bull 57: 293-296.

FERRAN JL, SÁNCHEZ-ARRONES L, SANDOVAL JE, PUELLES L (2007). A model of early molecular regionalization in the chicken embryonic pretectum. J Comp Neurol 505: 379-403.

FERRAN JL, SÁNCHEZ-ARRONES L, BARDET SM, SANDOVAL J, MARTÍNEZDE-LA-TORRE M, PUELLES L (2008). Early pretectal gene expression pattern shows a conserved anteroposterior tripartition in mouse and chicken. Brain Res Bull 75: 295-298.

FERRÁN JL, DUTRA DE OLIVEIRA E, SÁNCHEZ-ARRONES L, SANDOVAL JE, MARTÍNEZ-DE-LA-TORRE M, PUELLES L (2009). Geno-architectonic analysis of regional histogenesis in the chicken pretectum. J Comp Neurol 517: 405-451.

FERRAN JL, PUELLES L, RUBENSTEIN JLR (2015). Molecular codes defining rostrocaudal domains in the embryonic mouse hypothalamus. Front.Neuroanat. 9:46. doi: 10.3389/fnana.2015.00046

FIGDOR MC, STERN CD (1993). Segmental organization of embryonic diencephalon. Nature 363: 630-634.

FRASER S, KEYNES R, LUMSDEN A (1990). Segmentation in the chick embryo hindbrain is defined by cell lineage restrictions. Nature 344: 431-435.

GARCíA-CALERO E, MARTÍNEZ-DE-LA-TORRE M, PUELLES L (2002). The avian griseum tectale: cytoarchitecture, NOS expression and neurogenesis. Brain Res Bull 57: 353-358.

GARCÍA-CALERO E, GARDA AL, PUELLES L (2006). The gene Lrrn1 marks the prospective site of the zona limitans thalami in the early embryonic chicken diencephalon. Gene Expr Patterns 6: 879-885.

GARCíA-CALERO E, FERNÁNDEZ-GARRE P, MARTíNEZ S, PUELLES L. (2008). Early mammillary pouch specification in the course of prechordal ventralization of the forebrain tegmentum. Dev Biol 320: 366-377.

GARCIA-LOPEZ R, POMBERO A, MARTINEZ S. (2009). Fate map of the chick embryo neural tube. Dev Growth Differ 51: 145-165.

GARCIA-LOPEZ R, VIEIRA C, ECHEVARRIA D, MARTINEZ S. (2004). Fate map of the diencephalon and the zona limitans at the 10-somites stage in chick embryos. Dev Biol 268: 514-530.

GARDA AL, ECHEVARRÍA D, MARTÍNEZ S (2001). Neuroepithelial co-expression of Gbx2 and Otx2 precedes Fgf8 expression in the isthmic organizer. Mech Dev 101: 111-118.

GASKELL W (1886). On the structure, distribution and function of the nerves which innervate the visceral and vascular systems. J Physiol 7: 1-81.

GASKELL W (1889). On the relation between the structure, function, distribution and origin of the cranial nerves; together with an theory of the origin of the nervous system of vertebrata. J Physiol 10: 153-211.

GAUNT SJ, MILLER JR, POWELL DJ, DUBOULE D. (1986). Homoeobox gene expression in mouse embryos varies with position by the primitive streak stage. Nature 324: 662-664.

GIMENO L, BRÛLET P, MARTíNEZ S (2003). Study of Fgf15 gene expression in developing mouse brain. Gene Expr Patterns 3: 473-481.

GIMENO L, HASHEMI R, BRÛLET P, MARTÍNEZS (2002). Analysis of Fgf15 expression pattern in the mouse neural tube. Brain Res Bull 57: 297-299.

GRAHAM A, BUTTS T, LUMSDEN A, KIECKER C (2014). What can vertebrates tell us about segmentation? Evodevo 5: 24.

GRIBNAU AAM, GEIJSBERTS LGM (1985). Morphogenesis of the brain in stages Rhesus monkey embryos. Adv Anat Embryol Cell Biol 1-69.

GUINAZU MF, CHAMBERS D, LUMSDEN A, KIECKER C (2007). Tissue interactions in the developing chick diencephalon. Neural Dev 13: 2: 25.

HERRICK CJ (1903). The doctrine of nerve components and some of its applications. J Comp Neurol 13: 301-312.

HERRICK CJ (1910). The morphology of the forebrain in amphibia and reptilia. J Comp Neurol 20: 413-547.

HERRICK CJ (1933). Morphogenesis of the brain. J Morphol 54: 233-258.

HERRICK CJ (1948). The Brain of the Tiger Salamander. Chicago: Chicago Univ. Press.

HEYMAN I, KENTA, LUMSDENA(1993). Cellular morphology and extracellular space at rhombomere boundaries in the chick embryo hindbrain. Dev Dyn 198: 241-253.

HEYMAN I, FAISSNER A, LUMSDEN A (1995). Cell and matrix specialisations of rhombomere boundaries. Dev Dyn 204: 301-315.

HIDALGO-SÁNCHEZ M, ALVARADO-MALLART RM (2002). Temporal sequence of gene expression leading caudal prosencephalon to develop a midbrain/hindbrain phenotype. Dev Dyn 223: 141-147.

HIDALGO-SÁNCHEZM, MARTÍNEZ-DE-LA-TORRE M, ALVARADO-MALLARTRM, PUELLES L (2005a). Distinct pre-isthmic domain, defined by overlap of Otx2 and Pax2 expression domains in the chicken caudal midbrain. JComp Neuro/483: 17-29.

HIDALGO-SÁNCHEZ M, MILLET S, BLOCH-GALLEGO E, ALVARADO-MALLART RM (2005b). Specification of the meso-isthmo-cerebellar region: the Otx2/Gbx2 boundary. Brain Res Brain Res Rev 49: 134-149.

HIDALGO-SÁNCHEZ M, SIMEONE A, ALVARADO-MALLART RM (1999). Fgf8 and Gbx2 induction concomitant with Otx2 repression is correlated with midbrainhindbrain fate of caudal prosencephalon. Development 126: 3191-3203.

HILL C (1899). Primary segments of the vertebrate head. Anat Anz 16: 335-369.

HILL C (1900). Developmental history of primary segments of the vertebrate head. Zool Jahrb Abt.Anat.u.Ontog. 13: 393-446.

HIS W (1870). Unsere Körperform und das Physiologische Problem ihrer Entstehung Briefe an einen befreundeten Naturforscher. Leipzig, Vogel Verlag.

HIS W (1892). Zur allgemeinen Morphologie des Gehirns. Arch Anat Entwickl-Gesch [Anatomische Abteilung des Arch $f$ Anat u Physiol] 2: 346-383.

HIS W (1893a). Über das frontale Ende des Gehirnrohrs. Arch Anat Entwickl-Gesch [Anatomische Abteilung des Arch $f$ Anat $u$ Physiol] 3: 157-171.

HIS W (1893b). Vorschläge zur Eintheilung des Gehirns. Arch Anat Entwickl-Gesch Jahrg 1893: 173-179.

HIS W (1894). Über die Vorstufen der Gehirn- und der Kofbildung bei Wirbelthieren (+ Table XXI). Arch Anat Entwickl-Gesch Jahrg 1894: 313-336.

HIS W (1895). Die Anatomische Nomenclatur, Nomina Anatomica. Neurol Suppl Bd, Arch Anat Entwickl-Gesch Jahrg 1895: 155-177.

HIS W (1904). Die Entwicklung des menschlichen Gehirns während der ersten Monate. Leipzig: Hirzel.

JOHNSTON JB (1902). An attempt to define the primitive functional divisions of the ccentral nervous system. J Comp Neurol 12: 87-106.

JOHNSTON JB (1909). The morphology of the forebrain vesicles in vertebrates. J Comp Neurol 19: 457-539.

KÄLLÉN B (1965). Early morphogenesis and pattern formation in the central nervous system. In: DeHaan-Urspeung Organogenesis, New York: Holt, pp 107-128.

KAPPERS CU, HUBER GC, CROSBY EC (1936). The Comparative Anatomy of the Nervous System of Vertebrates, including Man. 2 vols. New York: Macmillan.

KAUFFMAN SA (1993). The Origin of Order: Self-Organization and Selection in Evolution. Oxford: Oxford Univ. Press.

KAUFFMAN SA (2008). Reinventing the Sacred. NewYork: Basic Books. 
KEYSER A (1972). The development of the diencephalon of the chinese hamster: an investigation of the validity of the criteria of subdivision of the brain. Acta Anat 83 (Suppl. 59).

KIECKER C, LUMSDEN A (2004). Hedgehog signaling from the ZLI regulates diencephalic regional identity. Nat Neurosci 7: 1242-1249.

KIECKER C, LUMSDEN A (2005). Compartments and their boundaries in vertebrate brain development. Nat Rev Neurosci 6: 553-564.

KIECKER C, LUMSDEN A (2009). Recent advances in neural development. F1000 Biol Rep. 1: 1.

KIECKER C, LUMSDEN A (2012). The role of organizers in patterning the nervous system. Annu Rev Neurosci 35: 347-367.

KRUMLAUF R, MARSHALL H, STUDER M, NONCHEV S, SHAM MH, LUMSDEN A (1993). Hox homeobox genes and regionalisation of the nervous system. $J$ Neurobiol 24: 1328-1340.

KUHLENBECKH(1927). Vorlesungen über das Zentralnervensystem der Wirbeltiere. Jena: Fischer.

KUHLENBECK H (1935). Über die morphologische Bewertung der sekundären Neuromerie. Anat Anz 81: 129-148.

KUHLENBECK H (1936). Über die Grundbestandteile des Zwischenhirnbauplans der Vögel. Morph Jahrb 77: 61-109.

KUHLENBECK H (1937). The ontogenetic development of the diencephalic centers in a bird's brain (chick) and comparison with the reptilian and mammalian diencephalon. J Comp Neurol 66: 23-75.

KUHLENBECK H (1939). The development and structure of the pretectal cell masses in the chick. J Comp Neurol 71: 361-357.

KUHLENBECK H (1954). The Human Diencephalon. Basel: Karger.

KUHLENBECK H (1973). The Central Nervous System of Vertebrates. Vol.3. part II: Overall Morphologic Pattern. Basel: Karger.

KUHLENBECKH(1975). The Central Nervous System of Vertebrates. Vol.5. part I:Derivatives of the Prosencephalon: Diencephalon and Telencephalon. Basel:Karger.

LARSEN CW, ZELTSER LM, LUMSDEN A (2001). Boundary formation and compartmentation in the avian diencephalon. J Neurosci 21: 4699-4711.

LE DOUARIN N (1969). Details du noyeau interphasique de la caille Japonaise (Coturnix coturnix japonica). Bull Biol Fr Belg 103: 435-452.

LE DOUARIN N, BARQ G (1969). Utilization des cellules de caille Japonaise comme "marqueurs biologiques en embryologie experimentelle. C R Acad Sci Hebd Seances Acad Sci D 269: 1543-1546.

LE DOUARIN NM, KALCHEIM C (1999). The Neural Crest (Developmental and Cell Biology Series) Cambridge: Cambridge Univ.Press

LE DOUARIN NM, DUPIN E (2012). The neural crest in vertebrate evolution. Curr Opin Genet Dev 22: 381-389.

LOCY WA (1895). Contribution to the structure and development of the vertebrate head. Thesis Univ.Chicago, Boston: Ginn \& Co.

LUMSDEN A (1990). The cellular basis of segmentation in the developing hindbrain. Trends Neurosci 13: 329-335.

LUMSDEN A (1991). Cell lineage restrictions in the chick embryo hindbrain. Philos Trans $R$ Soc Lond B Biol Sci 331: 281-286.

LUMSDEN A, KEYNES R. (1989). Segmental patterns of neuronal development in the chick hindbrain. Nature 337: 424-428.

LYSER KM (1966). The development of the chick diencephalon and mesencephalon during the initial phases of neuroblast differentiation. J Embryol exp Morph 16: 497-517.

MALPIGHI M (1673). Dissertatio epistolica de formatione pulli in ovo. London, UK.

MARÍN F, PUELLES L (1994). Patterning of the embryonic avian midbrain after experimental inversions: a polarizing activity from the isthmus. Dev Biol 163: 19-37.

MARÍN F, PUELLES L (1995). Morphological fate of rhombomeres in quail/chick chimeras: a segmental analysis of hindbrain nuclei. Eur J Neurosci 7: 1714-1738.

MARÍN F, AROCA P, PUELLES L (2008). Hox gene colinear expression in the avian medulla oblongata is correlated with pseudorhombomeric domains. Devel Biol 323: $230-247$.

MARTÍNEZ S (2001)The isthmic organizer and brain regionalization. Int J Dev Biol 45: 367-371.

MARTINEZS, ALVARADO-MALLART RM (1989). Rostral cerebellum originates from the caudal portion of the so-called 'mesencephalic' vesicle: a study using chick quail chimeras. Eur J Neurosci 1: 549-560.

MARTINEZ S, ALVARADO-MALLART RM (1990). Expression of the homeobox cEn gene in chick/quail chimeras with inverted mes-metencephalic grafts. Dev Biol 139: $432-436$

MARTÍNEZ S, ALVARADO-MALLART RM, MARTÍNEZ DE LA TORRE M, PUELLES L. (1991a). Retinal and tectal connections of embryonic nucleus superficialis magnocellularis and its mature derivates in the chick. Anat. Embryol. 183:235-243.

MARTINEZ S, WASSEF M, ALVARADO-MALLART RM (1991b). Induction of a mesencephalic phenotype in the 2-day-old chick prosencephalon is preceded by the early expression of the homeobox gene En. Neuron 6: 971-981.

MARTINEZ S, GEIJO E, SÁNCHEZ-VIVES MV, PUELLES L, GALLEGO R. (1992) Reduced junctional permeability at interrhombomeric boundaries. Development 116: $1069-1076$

MARTÍNEZS, MARÍNF, NIETOMA, PUELLESL(1995). Induction of ectopic engrailed expression and fate change in avian rhombomeres: intersegmental boundaries as barriers. Mech Dev 51: 289-303.

MARTINEZS, CROSSLEYPH, COBOSI, RUBENSTEINJL, MARTINGR(1999). FGF8 induces formation of an ectopic isthmic organizer and isthmocerebellar development via a repressive effect on Otx2 expression. Development 126: 1189-1200.

MARTÍNEZS, PUELLES E, PUELLES L, ECHEVARRIAD (2012). Molecular regionalization of developing neural tube. Chapter 1 in "The Mouse Nervous System". Watson C, Paxinos G, Puelles L (eds). Academic Press/Elsevier; pp 2-18.

MARTÍNEZ DE LA TORRE M (1985). Estructura del mesencéfalo y diencéfalo en aves y reptiles: Aportaciones a una síntesis en la búsqueda de homologías. PhD thesis in Medicine. Univ. of Murcia, Spain.

MARTÍNEZ-DE-LA-TORRE M, GARDAA-L, PUELLES E, PUELLES L (2002). Gbx2 expression in the late embryonic chick dorsal thalamus. Brain Res Bull57:435-438.

MARTINEZ-FERREA, NAVARRO-GARBERI M, BUENO C, MARTINEZS (2013). Wnt signal specifies the intrathalamic limit and its organizer properties by regulating Shh induction in the alar plate. J Neurosci 33: 3967-3980.

MCCLURE CFW (1890). The segmentation of the primitive vertebrate brain J.Morphol. 4:35-56.

MERCHÁN P, BARDET SM, PUELLES L, FERRAN JL (2011). Comparison of pretectal genoarchitectonic pattern between quail and chicken embryos. Fron Neuroanat 2011, 5: 23

MILLET S, BLOCH-GALLEGO E, SIMEONE A, ALVARADO-MALLART RM (1996). The caudal limit of Otx2 gene expression as a marker of the midbrain/hindbrain boundary: a study using in situ hybridization and chick/quail homotopic grafts. Development 122: 3785-3797.

MILLET S, CAMPBELL K, EPSTEIN DJ, LOSOS K, HARRIS E, JOYNER AL (1999). A role for $\mathrm{Gbx} 2$ in repression of Otx2 and positioning the mid/hindbrain organizer Nature 401: 161-164.

MORONA R, FERRAN JL, PUELLES L, GONZÁLEZ A (2011). Embryonic genoarchitecture of pretectum in Xenopus laevis: a conserved pattern in tetrapods. $J$ Comp Neurol 519: 1024-1050.

MURPHY P, DAVIDSON DR, HILL RE. (1989). Segment-specific expression of a homoeobox-containing gene in the mouse hindbrain. Nature 341: 156-159.

NEAL HV (1898). The segmentation of the nervous system in Squalus acanthias. A contribution to the morphology of the vertebrate head. Bull Mus Comp Zool Harvard College 31: 1-294.

NEAL HV (1919). Neuromeres and metameres. J Morphol 31: 293-315.

NIEUWENHUYS R, PUELLES L (2016). Towards a New Neuromorphology. Berlin, Springer Verlag. (ISBN: 978-3-319-25692-4).

NIEUWENHUYS R, VOOGD J, VAN HUIJZEN C (2008). The Human Central Nervous System, 4th edit. Berlin: Springer.

ORR HA (1887). Contributions to the embryology of the lizard. J Morphol 1: 311-373.

PALMGREN A (1921). Embryological and morphological studies on the midbrain and cerebellum of vertebrates. Acta Zool 2: 1-94.

PEUKERTD, WEBERS, LUMSDENA, SCHOLPPS (2011). Lhx2 and Lhx9 determine neuronal differentiation and compartition in the caudal forebrain by regulating $\mathrm{Wnt}$ signaling. PLoS Biol. 9:1001218.

POMBERO A, MARTINEZ S (2009). Telencephalic morphogenesis during the process of neurulation: an experimental study using quail-chick chimeras. J Comp Neurol 512: 784-797 
PUELLES L (1978). A Golgi-study of oculomotor neuroblasts migrating across the midline in chick embryos. Anat Embryol 152: 205-215.

PUELLESL(1995). Asegmental morphological paradigm for understanding vertebrate forebrains. Brain Behav Evol 46: 319-337.

PUELLES L (2009). Contributions to neuroembryology of Santiago Ramón y Cajal. Int J Dev Biol 53: 1145-1160.

PUELLES L (2009-2011). Reference atlases for the Allen Developing Mouse Brain Atlas; www.developingmouse.brain-map.org

PUELLES L (2013). Plan of the developing vertebrate nervous system relating embryology to the adult nervous system (prosomere model, overview of brain organization), In Comprehensive Developmental Neuroscience: Patterning and Cell Type Specification in the Developing CNS and PNS. (J.L.R. Rubenstein and P. Rakic eds.) Amsterdam: Academic Press, pp. 187-209.

PUELLES L (2016). Comments on the limits and internal structure of the mammalian midbrain. Anatomy [Intl.J.Exp.\&Clin Anat] 10: 60-70.

PUELLES L (2017). Forebrain development in vertebrates: The evolutionary role of secondary organizers. In The Wiley Handbook of Evolutionary Neuroscience. (S.V. Shepherd, ed.) Chichester, West Sussex:Wiley/Blackwell, pp.350-387. (ISBN 978-11-1999-469-5).

PUELLES L, BENDALA MC (1978). Differentiation of neuroblasts in the chick optic tectum up to the eight day of incubation: a Golgi study. Neuroscience 3: 207-325.

PUELLES L MARTINEZ S (2013). Patterning of the diencephalon, In Comprehensive Developmental Neuroscience: Patterning and Cell Type Specification in the Developing CNS and PNS (J.L.R. Rubenstein and P. Rakic eds.). Amsterdam: Academic Press, pp. 151-172.

PUELLES L, MEDINA L (2002). Field homology in the brain and elsewhere: can it resolve genetic and morphogenetic variability problems in homology? Brain Res Bull 57: 243-256.

PUELLES L, PRIVAT J (1977). Do oculomotor neuroblasts migrate across the midline in the fetal rat brain. Anat Embryol 150: 187-206.

PUELLES L, RUBENSTEIN JLR (1993). Expression patterns of homeobox and other putative regulatory genes in the embryonic mouse forebrain suggest a neuromeric organization. Trends Neurosci 16: 472-479.

PUELLES L, RUBENSTEIN JLR. (2003). Forebrain gene expression domains and the evolving prosomeric model. Trends Neurosci 26: 469-476.

PUELLES L, RUBENSTEIN JLR (2015). A new scenario of hypothalamic organization: rationale of new hypotheses introduced in the updated prosomeric model. Front. Neuroanat. 9:27. (doi: 10.3389/fnana.2015.00027).

PUELLES L, MALAGÓN F, GENIS-GÁLVEZ JM (1975). The migration of oculomotor neuroblasts across the midline in the chick embryo. Exp Neurol 47: 459-469.

PUELLES L, AMAT JA, MARTÍNEZ DE LA TORRE M (1987b). Segment-related, mosaic neurogenetic pattern in the forebrain and mesencephalon of early chick embryos. I. Topography of AChE-positive neuroblasts up to stage HH18. J Comp Neurol 266: 147-268.

PUELLES L, MARÍN F, MARTÍNEZ S, MARTÍNEZ-DE-LA-TORRE M (1996). The midbrain-hindbrain junction: A model system for brain regionalization through morphogenetic neuroepithelial interactions. In Mammalian Development. (P.Lonai, ed.). Gordon \& Breach/Harwood Academic Publishers, Amsterdam. pp 173-197.

PUELLES L, KUWANA E, PUELLES E, KELEHER J, BULFONE A, RUBENSTEIN JLR (2000). Pallial and subpallial derivatives in the chick and mouse telencephalon, traced by the embryonic expression profiles of the genes Dlx-2, Emx-1, Nkx-2.1, Pax-6 and Tbr-1. J Comp Neurol 424: 409-438.

PUELLESL, MARTÍNEZS, MARTÍNEZ-DE-LA-TORREM, RUBENSTEINJLR (2004). Gene maps and related histogenetic domains in the forebrain and midbrain. In: The Rat Nervous System, Third Edition, G.Paxinos (ed), Academic Press, San Diego, CA, pp. 3-25.

PUELLES L, MARTÍNEZ-DE-LA-TORRE M, PAXINOS G, WATSON C, MARTÍNEZS (2007). The Chick Brain in Stereotaxic Coordinates: an Atlas featuring Neuromeric Subdivisions and Mammalian Homologies. San Diego: Elsevier/Academic Press.

PUELLES L, MARTíNEZ S, MARTÍNEZ-DE-LA-TORRE M (2008). Texto de Neuroanatomía. Buenos Aires: Ed.Médica Panamericana.

PUELLESL, MARTINEZ-DE-LA-TORREM, BARDETS, RUBENSTEIN JLR (2012a). Hypothalamus. Chapter 8 in "The Mouse Nervous System". Watson C, Paxinos G, Puelles L (eds). Academic Press/Elsevier; pp221-312.

PUELLES E, MARTINEZ-DE-LA-TORRE M, WATSON C, PUELLES L (2012b).
Midbrain. Chapter 10 in «The Mouse Nervous System ». Watson C, Paxinos G, Puelles L (eds). Academic Press/Elsevier; pp. 337-359.

PUELLES L (2013). Plan of the developing vertebrate nervous system relating embryology to the adult nervous system (prosomere model, overview of brain organization), In Comprehensive Developmental Neuroscience: Patterning and Cell Type Specification in the Developing CNS and PNS. (J.L.R. Rubenstein and P. Rakic eds.). Amsterdam: Academic Press, pp. 187-209.

PUELLESL, DOMÉNECH-RATTOG, MARTÍNEZ-DE-LA-TORREM (1987a). Location of the rostral end of the longitudinal brain axis: Review of an old topic in the light of marking experiments on the closing rostral neuropore. J Morphol 194: 163-171

PUELLES L, GUILLÉN M, MARTÍNEZ DE LATORRE M. (1991). Observations on the fate of nucleus superficialis magnocellularis of Rendahl in the avian diencephalon, bearing on the organization and nomenclature of neighboring retinorecipient nuclei. Anat. Embryol. 183: 221-233.

PUELLES L, MARTINEZ-DE-LA-TORRE M (1987). Autoradiographic and Golgi study on the early development of $\mathrm{n}$. isthmi principalis and adjacent grisea in the chick embryo : a tridimensional viewpoint. Anat Embryol 176: 19-34.

PUELLES L, ROBLES C, MARTÍNEZ-DE-LA-TORRE M, MARTíNEZS. (1994). New subdivision schema for the avian torus semicircularis: neurochemical maps in the chick. J Comp Neurol 340: 98-125.

RENDAHL H (1924). Embryologische und morphologische Studien über das Zwischenhirn beim Huhn. Acta Zool 5: 241-344.

RUBENSTEINJL, MARTINEZS, SHIMAMURAK, PUELLESL (1994). The embryonic vertebrate forebrain: the prosomeric model. Science 266: 578-580.

RUBENSTEIN JLR, SHIMAMURAK, MARTÍNEZS, PUELLESL(1998). Regionalization of the prosencephalic neural plate. Ann Rev Neurosci 21: 445-477.

SÁNCHEZ-ARRONES L, FERRÁN JL, RODRÍGUEZ-GALLARDO L, PUELLES L (2009). Incipient forebrain boundaries traced by differential gene expression and fate mapping in the chick neural plate. Devel Biol 335: 43-65.

SÁNCHEZ-ARRONES L, STERN CD, BOVOLENTA P, PUELLES L (2012). Sharpening of the anterior neural border in the chick by rostral endoderm signalling Development 139: 1034-1044.

SÁNCHEZ-ARRONES L, FERRÁN JL, HIDALGO-SANCHEZ M AND PUELLES L (2015). Origin and early development of the chicken adenohypophysis. Front. Neuroanat. doi: 10.3389/fnana.2015.00007.

SANDERS TA, LUMSDENA, RAGSDALE CW (2002). Arcuate plan of chick midbrain development. J Neurosci 22: 10742-10750.

SCHOLPP S, LUMSDEN A (2010). Building a bridal chamber: development of the thalamus. Trends Neurosci 33: 373-380.

SCHOLPP S, FOUCHER I, STAUDT N, PEUKERT D, LUMSDEN A, HOUART C (2007). Otx1l, Otx2 and Irx1b establish and position the ZLI in the diencephalon. Development 134: 3167-3176.

SCHOLPP S, WOLF O, BRAND M, LUMSDEN A (2006). Hedgehog signalling from the zona limitans intrathalamica orchestrates patterning of the zebrafish diencephalon. Development 133: 855-864.

SHIMAMURA K, HARTIGAN DJ, MARTINEZ S, PUELLES L, RUBENSTEIN JL. (1995). Longitudinal organization of the anterior neural plate and neural tube. Development 121: 3923-3933.

SHIMAMURA K, MARTINEZ S, PUELLES L, RUBENSTEIN JL. (1997). Patterns of gene expression in the neural plate and neural tube subdivide the embryonic forebrain into transverse and longitudinal domains. Dev Neurosci 19: 88-96.

SHIMOGORI T, LEE DA, MIRANDA-ANGULO A, YANG Y, WANG H, JIANG L, YOSHIDAAC, KATAOKAA, MASHIKO H, AVETISYAN M, QI L, QIAN J, BLACKSHAW $S$ (2010). A genomic atlas of mouse hypothalamic development. Nat NeurosC 13: $767-775$

STREETER GL (1933). The status of metamerism in the central nervous system of chick embryos. J Comp Neurol 57: 455-475.

SUNDIN OH, EICHELE G. (1990). A homeo domain protein reveals the metameric nature of the developing chick hindbrain. Genes Dev 4: 1267-1276.

SWANSON LW (2003). Brain Architecture: Understanding the Basic Plan. 1st edit. Oxford: Oxford Univ. Press.

SWANSON LW (2012). Brain Architecture: Understanding the Basic Plan. 2nd edit. Oxford: Oxford Univ. Press.

TAN K, LE DOUARIN NM (1991)Development of the nuclei and cell migration in the medulla oblongata. Application of the quail-chick chimera system. Anat Embryol 


\section{L.Puelles}

(Berl) 183: 321-343.

TELLO JF (1923). Les différenciations neuronales dans l'embryon de poulet, pendant les premiers jours de l'incubation. Trab Lab Invest Biol 21: 1-94.

TELLO JF (1934). Les differenciations neurofibrilaires dans le prosencephale de la souris de 4 a 15 millimètres. Trab Lab Invest Biol 29: 339-396.

TOMÁS-ROCAL, CORRAL-SAN-MIGUELR,AROCAP, PUELLES L, MARÍNF (2016). Crypto-rhombomeres of the mouse medulla oblongata, defined by molecular and morphological features. Brain Struct Funct 221: 815-838.

VAAGE S (1969). The segmentation of the primitive neural tube in chick embryos (Gallus domesticus). Ergeb Anat Entwicklungsgesch 41: 1-88.

VAAGE S (1973). The histogenesis of the isthmic nuclei in chick embryos (Gallus domesticus).I. A morphological study. Z Anat Entwicklungsgesch 142: 283-314.

VIEIRA C, GARCIA-LOPEZ R, MARTÍNEZ S (2006). Positional regulation of Pax2 expression pattern in mesencephalic and diencephalic alar plate. Neuroscience 137: 7-11.

VIEIRAC, POMBEROA, GARCIA-LOPEZR, GIMENO L, ECHEVARRÍAD, MARTINEZ $S$ (2010). Molecular mechanisms controlling brain development: an overview of neuroepithelial secondary organizers. Int J Dev Biol 54: 7-20.

VON KUPFFERK (1906). Die Morphogenie des Centralnervensystems. In Handbuch der Vergleichenden und Experimentellen Entwicklungslehre der Wirbeltiere. Vol2, Part III. (Hertwig O, ed.). Jena: Fischer, pp1-272.

WASSARMAN KM, LEWANDOSKI M, CAMPBELL K, JOYNER AL, RUBENSTEIN JL, MARTINEZ S, MARTIN GR (1997). Specification of the anterior hindbrain and establishment of a normal mid/hindbrain organizer is dependent on Gbx2 gene function. Development 124: 2923-2934.
WASSEFM, BALLY-CUIFL, ALVARADO-MALLARTRM (1993). Regional specification during cerebellar development. Perspect Dev Neurobiol 1: 127-132.

WATSON C, SHIMOGORI T, PUELLES L (2017). Mouse FGF8-Cre lineage analysis defines the territory of the postnatal mammalian isthmus. J Comp Neurol 525: 2782-2799.

WEDIN B (1955). Embryonic segmentations in the head. Malmö: Lundgrens Söners. pp.1-115.

WILKINSON DG, BHATTS, CHAVRIERP, BRAVOR, CHARNAYP. (1989a). Segmentspecific expression of a zinc-finger gene in the developing nervous system of the mouse. Nature 337: 461-464.

WILKINSON DG, BHATT S, COOK M, BONCINELLI E, KRUMLAUF R. (1989b) Segmental expression of Hox-2 homeobox-containing genes in the developing mouse hindbrain. Nature 341: 405-409.

WINDLE WF, AUSTIN MF (1936). Neurofibrillar development in the central nervous system of chick embryos up to 5 days of incubation. J Comp Neurol 63: 431-463.

WINGATE RJ, LUMSDEN A (1996). Persistence of rhombomeric organization in the postsegmental hindbrain. Development 122: 2143-2152.

ZABALA GIMÉNEZ MC (1978). Estudio morfológico de la neurohistogénesis en el diencéfalo del embrión de pollo, en correlación con el desarrollo de la vía óptica. PhD Thesis in Sciences. Univ. of Sevilla, Spain

ZELTSER LM, LARSEN CW, LUMSDENA (2001). Anew developmental compartment in the forebrain regulated by Lunatic fringe. Nat Neurosci 4: 683-684.

ZIEHEN T (1906). Die Morphogenie des Zentralnervensystems der Säugetiere. In Handbuch der vergleicgenden und experimentellen Entwicklungslehre der Wirbeltiere. Vol 2, (Hertwig O., ed.). Jena : Fischer. pp 273-368. 


\section{Further Related Reading, published previously in the Int. J. Dev. Biol.}

Retinoid signalling is required for information transfer from mesoderm to neuroectoderm during gastrulation

Ferran Lloret-Vilaspasa, Hans J. Jansen, Koen de Roos, Rosh A.S. Chandraratna, Maija H. Zile, Claudio D. Stern and Antony J. Durston Int. J. Dev. Biol. (2010) 54: 599-608

https://doi.org/10.1387/ijdb.082705fl

Contributions to Neuroembryology of Santiago Ramon y Cajal (1852-1934) and Jorge F. Tello (1880-1958)

Luis Puelles

Int. J. Dev. Biol. (2009) 53: 1145-1160

https://doi.org/10.1387/ijdb.082589lp

Molecular mechanisms controlling brain development: an overview of neuroepithelial secondary organizers

Claudia Vieira, Ana Pombero, Raquel García-Lopez, Lourdes Gimeno, Diego Echevarria and Salvador Martínez

Int. J. Dev. Biol. (2010) 54: 7-20

https://doi.org/10.1387/ijdb.092853cv

Spatiotemporal clustering of cell death in the avian forebrain proliferative zone

Christine J. Charvet and Georg F. Striedter

Int. J. Dev. Biol. (2008) 52: 345-352

https://doi.org/10.1387/ijdb.072455cc

Mammalian neural tube grafting experiments: an in vitro system for mouse experimental embryology

D Echevarría, C Vieira and S Martínez

Int. J. Dev. Biol. (2001) 45: 895-902

http://www.intjdevbiol.com/web/paper/11804033

5 yr ISI Impact Factor $(2016)=2.421$
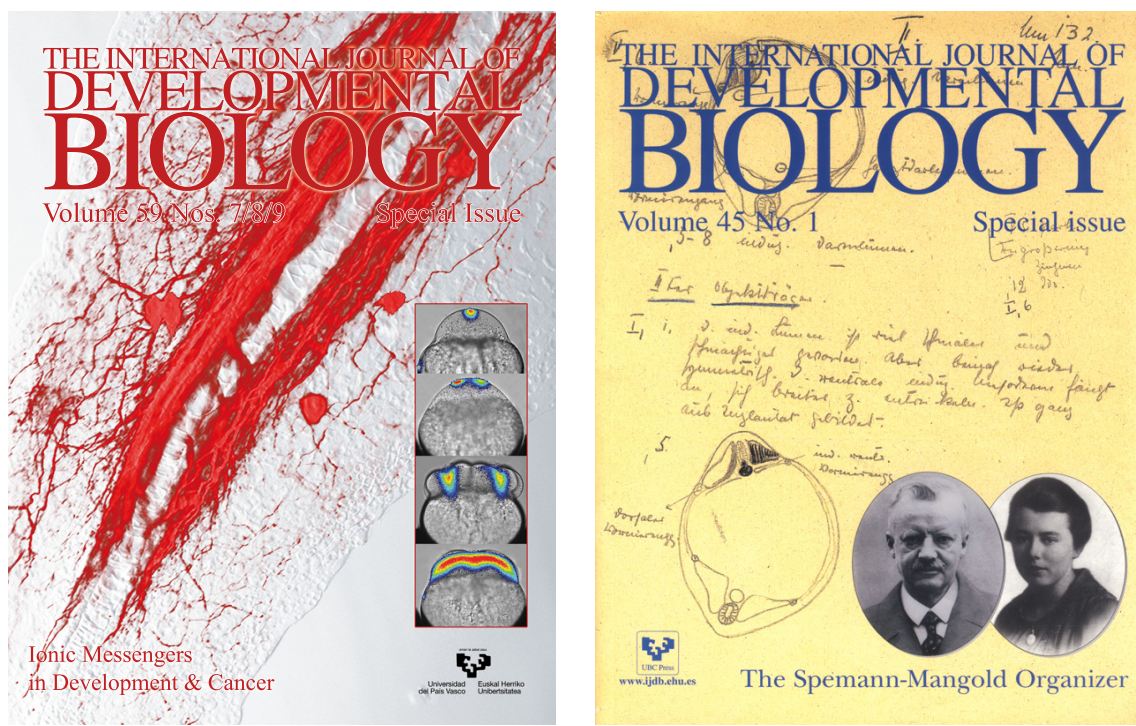

Volume 45 No. 1

Special issue
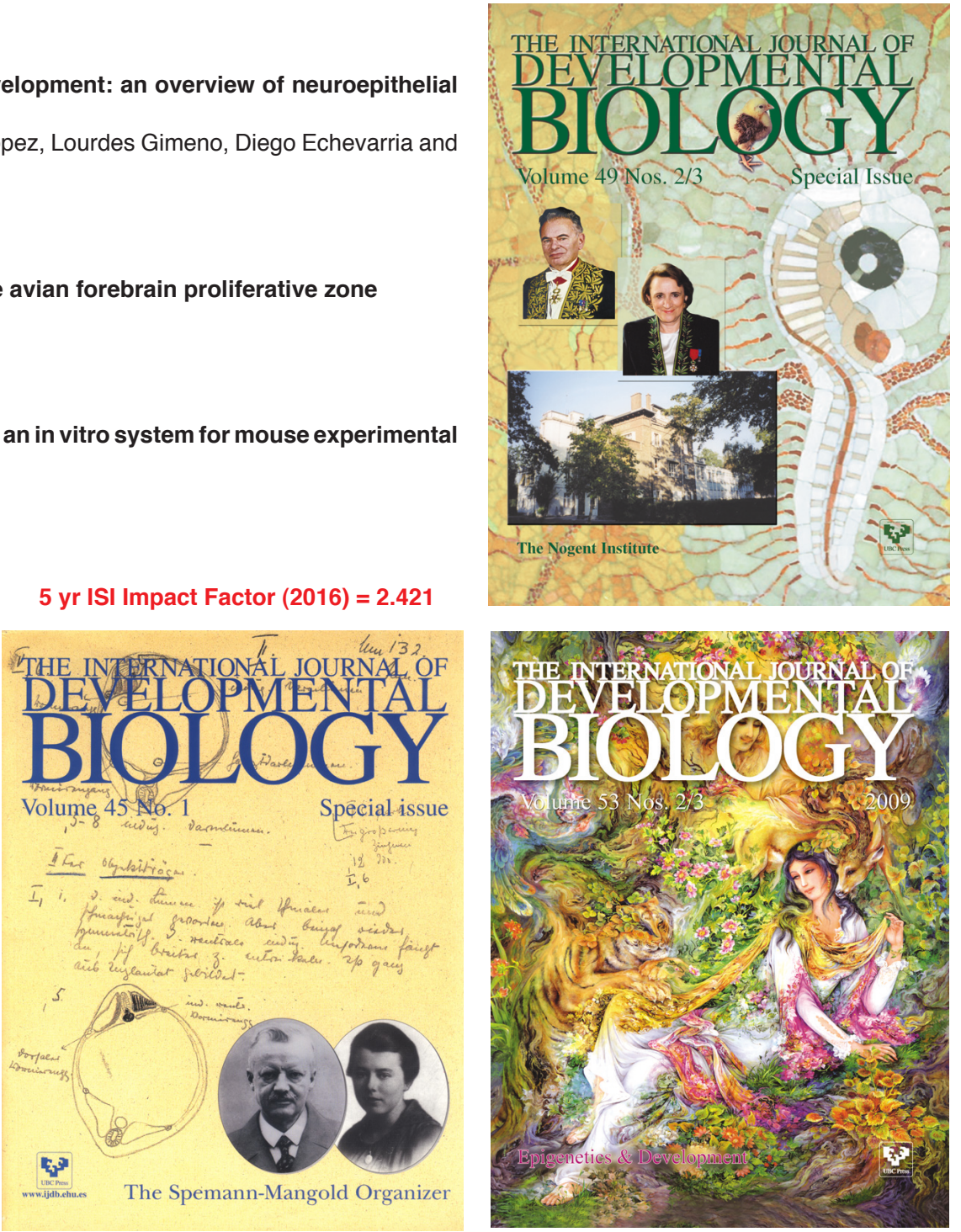